Archimer, archive institutionnelle de l'Ifremer Vol. 76, Issues 3-4 , 10 March 2006, Pages 278-294 http://www.ifremer.fr/docelec/ http://dx.doi.org/10.1016/j.aquatox.2005.10.004 (c) 2005 Elsevier B.V. All rights reserved

\title{
Impact of acute cadmium exposure on the trunk lateral line neuromasts and consequences on the "C-start" response behaviour of the sea bass (Dicentrarchus labrax L.; Teleostei, Moronidae)
}

\author{
Karine Faucher ${ }^{a, b}{ }^{, *}$, Denis Fichet ${ }^{b}$, Pierre Miramand ${ }^{b}$ and Jean Paul Lagardère ${ }^{a,{ }^{* *}}$
}

\author{
${ }^{\mathrm{a} C e n t r e ~ d e ~ R e c h e r c h e ~ s u r ~ l e s ~ E c o s y s t e ̀ m e s ~ M a r i n s ~ e t ~ A q u a c o l e s, ~ C N R S-I f r e m e r, ~ B P ~ 5, ~} 17137$ \\ L'Houmeau, France \\ baboratoire de Biologie et Environnement Marins, FRE 2727, CNRS-Université de La Rochelle, \\ Avenue Michel Crépeau, 17042 La Rochelle, France \\ *: kfaucher@ifremer.fr \\ ** : jplagard@ifremer.fr
}

\begin{abstract}
:
Behavioural responses of sea bass Dicentrarchus labrax were investigated after exposure to cadmium ions in laboratory-controlled conditions. The aim of this study was to discover whether environmental exposure to cadmium ions inactivates fish lateral line system neuromasts, and to determine the behavioural consequences of such a sensory blockage. For this, fish escape behaviour in response to an artificial water jet was recorded using a 25-frames $\mathrm{s}^{-1}$ analog video camera before and after cadmium exposure. Experimental set up was tested with fish whose lateral line system was artificially inactivated by antibiotics (gentamicin and streptomycin). Histological analyses with scanning electron microscopy showed antibiotic treatment destroyed lateral line system neuromasts. In addition, these fish did not respond to stimulations provoked by the water jet after antibiotic treatment. Fish escape behaviour was then recorded before and after cadmium exposure at two different concentrations. When fish were exposed to the first concentration of cadmium tested $\left(0.5 \mu \mathrm{g} \mathrm{I}^{-1}\right.$, which represents the maximal cadmium concentration encountered in contaminated estuaries), no alteration in neuromast tissue was observed. In addition, before cadmium exposure, fish responded positively in $98.41 \pm 4.95 \%$ of lateral line system stimulations (escape behaviour in response to the water jet). After cadmium exposure, no behavioural modification could be detected: the fish responded positively in $95.16 \pm 9.79 \%$ of stimulations $\left(x^{2}=2.464, p=0.116\right)$. In contrast, the high cadmium concentration used $\left(5 \mu \mathrm{g} \mathrm{I} \mathrm{I}^{-1}\right.$, which represents 10 times the concentration occurring in highly polluted estuarine areas) involved severe neuromast tissue damage. Just after such cadmium exposure, fish showed only $41.67 \pm 35.36 \%$ of positive responses to their lateral line system stimulations, while they responded positively in $95.93 \pm 9.10 \%$ of stimulations under control conditions $\left(x^{2}=24.562\right.$, $p<0.0001)$. Their lateral line system neuromasts seemed to regenerate about 1 month after cadmium exposure. Associated with this regeneration, from the 21st day after cadmium exposure, their escape behaviour had recovered and was not significantly different from that recorded under control conditions $\left(86.74 \pm 20.82 \%, X^{2}=2.876, p=0.090\right)$. This study shows that although $5 \mu \mathrm{g} \mathrm{I}^{-1}$ cadmium is able to damage lateral line system neuromasts and causes fish behavioural alterations, fish exposed to $0.5 \mu \mathrm{g} \mathrm{I}^{-1}$ cadmium displayed neither tissue neuromast nor behavioural modification.
\end{abstract}

Keywords: Fish; Sea bass; Lateral line system; Neuromast; Acute cadmium exposure; C-start; Escape behaviour 


\section{Abstract}

Behavioural responses of sea bass Dicentrarchus labrax were investigated after exposure to cadmium ions in laboratory controlled conditions. The aim of this study was to discover whether environmental exposure to cadmium ions inactivates fish lateral line system neuromasts, and to determine the behavioural consequences of such a sensory blockage. For this, fish escape behaviour in response to an artificial water jet was recorded using a 25frames. $\mathrm{s}^{-1}$ analog video camera before and after cadmium exposure. Experimental set up was tested with fish whose lateral line system was artificially inactivated by antibiotics (gentamicin and streptomycin). Histological analyses with scanning electron microscopy showed antibiotic treatment destroyed lateral line system neuromasts. In addition, these fish did not respond to stimulations provoked by the water jet after antibiotic treatment. Fish escape behaviour was then recorded before and after cadmium exposure at two different concentrations. When fish were exposed to the first concentration of cadmium tested $\left(0.5 \mu \mathrm{g} . \mathrm{l}^{-}\right.$ ${ }^{1}$, which represents the maximal cadmium concentration encountered in contaminated estuaries), no alteration in neuromast tissue was observed. In addition, before cadmium exposure, fish responded positively in $98.41 \pm 4.95 \%$ of lateral line system stimulations (escape behaviour in response to the water jet). After cadmium exposure, no behavioural modification could be detected: the fish responded positively in $95.16 \pm 9.79 \%$ of stimulations $\left(\chi^{2}=2.464, p=0.116\right)$. In contrast, the high cadmium concentration used (5 $\mu \mathrm{g} . \mathrm{l}^{-1}$, which represents ten times the concentration occurring in highly polluted estuarine areas) involved severe neuromast tissue damage. Just after such cadmium exposure, fish showed only $41.67 \pm 35.36 \%$ of positive responses to their lateral line system stimulations, while they responded positively in $95.93 \pm 9.10 \%$ of stimulations under control conditions $\left(\chi^{2}=24.562, \mathrm{p}<0.0001\right)$. Their lateral line system neuromasts seemed to regenerate about 
one month after cadmium exposure. Associated with this regeneration, from the $21^{\text {st }}$ day after cadmium exposure, their escape behaviour had recovered and was not significantly different from that recorded under control conditions $\left(86.74 \pm 20.82 \%, \chi^{2}=2.876, p=0.090\right)$. This study shows that although $5 \mu \mathrm{g} .1^{-1}$ cadmium is able to damage lateral line system neuromasts and causes fish behavioural alterations, fish exposed to $0.5 \mu \mathrm{g} . \mathrm{l}^{-1}$ cadmium displayed neither tissue neuromast nor behavioural modification.

Key words: Fish, sea bass, lateral line system, neuromast, acute cadmium exposure, C-start, escape behaviour.

\section{Introduction}

In fish, lateral line system is involved in many behavioural events such as predator and prey detection (Hoekstra and Janssen, 1986; Montgomery, 1989; Bleckmann, 1993; Montgomery and Hamilton, 1997; Coombs, 1999; Janssen et al., 1999), rheotaxis (Bleckmann, 1993, Pavlov and Tyuryukov, 1993; Montgomery et al., 1997; Northcutt, 1997; Baker and Montgomery, 1999a, b; Coombs et al., 2001), obstacle avoidance (Dijkgraaf, 1962; Blaxter and Batty, 1985; Bleckmann, 1993) and intraspecific interactions (Partridge and Pitcher, 1980; Janssen et al., 1995). The morphological and functional integrity of this sensory system thus appears indispensable for the existence and the survival of a species in an ecosystem. In order to study the behavioural consequences of a blockage (temporary or permanent) of the lateral line system, several techniques have been used to inactivate this sensory system in many fish species. First, the oldest method is to section the trunk lateral lines on both sides just behind the operculum (Pitcher et al., 1976; Partridge and Pitcher, 1980; Partridge, 1982; New et al., 2001). Another technique used to damage both superficial 
and canal neuromasts of the fish lateral line system is of a mechanical nature. The most widespread method of doing this consists of ablating the superficial neuromasts by slightly scratching the lateral line epidermis in the rostrocaudal and caudorostral directions using a sterile razor blade (Montgomery et al., 1997; Baker and Montgomery, 1999a, b; Coombs et al., 2001). Another method, (Blaxter and Fuiman, 1989), is to assault the fish vigorously with turbulence and bubbles in order to dislodge superficial neuromast cupulae, making the neuromasts non-functional. To inactivate the canal neuromasts of a freshwater fish, AbdelLatif et al. (1990) pushed hairs through their pores until the lumen of all canals was filled completely, thereby preventing any fluid movement within them. Two other techniques are also widely used: antibiotic baths and treatment with cobalt. Antibiotics from the family of aminoglycosides are known to displace calcium ions from their fixation sites, thus blocking the cation channels located at the apices of the stereocilia of neuromast hair cells on the fish lateral line system (Hudspeth, 1983; Kroese et al., 1989; Forge and Schacht, 2000). Among these aminoglycosides, gentamicin acts selectively on canal neuromasts of the fish lateral line system (Song et al., 1995; Montgomery et al., 1997; Baker and Montgomery, 1999a, b; Coombs et al., 2001). This action of gentamicin is reversible at low concentration (Wersäll and Flock, 1964) whereas at high concentration, the effects induced by this antibiotic lead to cell death (Kaus, 1987; Richardson and Russel, 1991). While gentamicin selectively destroys canal neuromasts, streptomycin is commonly used to damage superficial neuromasts (Blaxter and Hoss, 1981; Kaus, 1987; Blaxter and Fuiman, 1989; Janssen et al., 1995; Higgs and Fuiman, 1996; Montgomery et al., 1997; Poling and Fuiman, 1997). Because exposure of fish to these antibiotics (gentamicin and streptomycin) does not affect the inner ear of fish (Matsuura et al., 1971; Blaxter and Fuiman, 1989), this method of blocking the lateral line system is of specific interest in fish-behaviour studies. After exposure to these antibiotics, both types of neuromasts regenerate within a period of between one and about 20 days after 
the end of the treatment, in both freshwater and seawater fish (Kaus, 1987; Blaxter and Fuiman, 1989; Song et al., 1995; Coombs et al., 2001). The use of cobalt chloride (CoCl2) in order to inactivate the fish lateral line system is also widely used. Sand (1975) previously developped this method using amphibians and it was then applied to freshwater fish (Karlsen and Sand, 1987; Enger et al., 1989; Janssen and Corcoran, 1993; Canfield and Rose, 1996; Liang et al., 1998; Abboud and Coombs, 2000). The action mode of cobalt is the same as that of antibiotics: this metal ion blocks calcium channels located at the apices of stereocilia on neuromast hair cells (Karlsen and Sand, 1987). According to the concentration used, the regeneration of neuromasts was observed between two and 30 days following the end of the treatment (Karlsen and Sand, 1987; Montgomery and Milton, 1993; Abboud and Coombs, 2000). However, Janssen (2000) demonstrated the toxicity of cobalt to fish. He showed that exposure of fish to high concentrations of cobalt causes significant perturbations of swimming behaviour and can lead to death. The efficacy of these techniques aimed at damaging the lateral line system of seawater or freshwater fish has rarely been demonstrated at the histological level for superficial and canal neuromasts. Only a few studies have been done to determine the tissue status of canal neuromasts after the use of gentamicin (Song et al. 1995; Coombs et al., 2001) and of superficial neuromasts after mechanical treatment alone or combined with application of cobalt (Baker and Montgomery, 1999a, b). Only one or two scanning electron micrographs have been published, showing the efficacy of these treatments. Except for those of Baker and Montgomery (1999b) and Coombs et al. (2001), few studies have mentioned the percentage of neuromasts destroyed by the treatment.

Because the lateral line system functions through ion flux, the presence of divalent metal cations, competing with $\mathrm{Ca}^{2+}$ cations at stereocilia level can disrupt neuromast hair cell function (Karlsen and Sand, 1987). Among metal ions, cadmium is considered as the most toxic ion after mercury because concentrations leading to death are much lower than for other 
metal ions (Eisler and Hennekey, 1977). Also, in contrast to several metal ions (copper, zinc, iron, cobalt, etc.), cadmium ion has no known metabolic role and does not seem to be biologically essential or beneficial to metabolism (Friberg et al., 1974; Bryan, 1979). Several studies concerning the contamination of coastal fish by metal ions, and by cadmium in particular, focused on the bio-accumulation of this metal in fish organs (Smith et al., 1976;

Cattani et al., 1996; Miramand et al., 1998; Al-Yousuf et al., 2000; Tayal et al., 2000; Scott et al., 2003; Tophon et al., 2003). These studies show that in seawater fish, cadmium accumulates mainly in the gills, liver, kidneys and muscles.

Given that cadmium is a calcium antagonist at the level of the gills (Verbost et al., 1987, 1988), and that calcium ions play a preponderant role in signal transduction mechanisms in neuromast hair cells in the fish lateral line system (Sand, 1975; Hudspeth and Corey, 1977; Jørgensen, 1984), cadmium ions might affect mechanoreception and thereby alter the behaviour of fish exposed to them. In general, during the approach of predators or other organisms, fish detect hydrodynamic stimuli caused by predator displacements that act on their lateral line system in association with the inner ear (Blaxter and Fuiman, 1989; Coombs et al., 1989; Bleckmann, 1993). The result is an escape response characterised by the fish body bent into a shape that resembles a "C" that earns it the term "C-start" or "startle response", followed by a sudden swimming acceleration produced by the propulsive movement of the caudal fin (Weihs, 1973; Blaxter and Fuiman, 1989; Canfield and Rose, 1996; Meyers et al., 1998; Casagrand et al., 1999; Eaton et al., 2001). This sudden reaction is initiated by Mauthner cells located in the cerebral trunk and the spinal cord of fish and amphibians (Zottoli, 1977, 1978; Zottoli et al., 1999). One could easily understand that a good initial perception of the "predator approach" stimulus by the lateral line system plays a preponderant role leading to the startle response. The aim of this study was to examine the effects of an acute exposure to cadmium, at concentrations akin to those encountered in a 
contaminated environment, on the lateral line system of the sea bass Dicentrarchus labrax, using both histological evaluation of neuromast damage and an analysis of changes in the frequency of the C-start behaviour.

\section{Material and methods}

\subsection{Animal origin and housing}

Experiments took place between October 2002 and June 2003 and between

December 2003 and July 2004. They comprised several sets of experiments, each one consisting of five fish (each fish was $6 \mathrm{~g}$ and $7 \mathrm{~cm}$ standard length). The standard length was measured from the tip of the snout up to the indentation of the fish caudal fin. Specimen sea bass were kindly donated by Vendée Aquaculture, La Faute sur Mer, France. They were placed in 4001 seawater tanks at constant temperature $\left(18^{\circ} \mathrm{C}\right)$ with a natural photoperiod for up to six weeks. They were fed twice a week with commercial pellets.

\subsection{Experimental set up}

$$
\text { temperature }\left(18^{\circ} \mathrm{C}\right) \text {. The photoperiod was controlled (14-L:10-D) and food was delivered by }
$$
an automatic feeder each day, about thirty minutes after the beginning of the light phase. Fish were placed for one week in this tank before the beginning of the experiment.

In order to test the function or the dysfunction of their lateral line system, a pipette connected to a syringe was hand-operated used to inject a water jet (about twenty ml per injection) between the water surface and the base of the tank when fish swam in the vicinity 
(about $5 \mathrm{~cm}$ ) of the pipette. The relatively shallow height of the water column (about $10 \mathrm{~cm}$ ) kept the fish at a depth close to that of the pipette producing the stimulation.

Each day, three stimulations (injection of a water jet with the syringe) were performed and the responses of the fish were recorded with an analog video camera (SONY CCD-VX1E Handicam Pro, 25-frames. $\mathrm{s}^{-1}$ ) positioned at a height of $\sim 1 \mathrm{~m}$ above the water surface. The lateral line system of the fish was considered as functional when the water jet stimulation provoked a sudden escape reaction, characterised by the bending of the fish's body into a C-like shape. This was followed by an abrupt swimming acceleration away from the initial location (fig. $1 \mathrm{~A}, \mathrm{~B}, \mathrm{C}$ ). The entire behaviour is called a C-start response (Eaton et al., 2001). Such a response was recorded as a positive response and noted 1. Immobility or a constant swimming velocity was noted as null response and noted 0 (fig. 1 D, E, F). Each day, the number of positive responses out of the three expected was calculated. In this way, sea bass were recorded each day under control conditions for three weeks.

\subsection{Fish lateral line system inactivation}

To ensure this experimental set up was successful, that is a non-functional lateral line system impeded fish from responding positively to stimulation based on the water jet, the lateral line system of sea bass was first deliberately inactivated using aminoglycoside antibiotics. This antibiotic-induced inactivation study was comprised of three experiments. For each experiment, after three weeks of fish response recording under control conditions, sea bass were collected and placed for $3 \mathrm{~h}$ in a 10 l-tank of seawater to which were added 0.5 g. $\mathrm{l}^{-1}$ streptomycin sulphate (Sigma) and 0.042 g..$^{-1}$ gentamicin sulphate (Sigma). The fish were then placed back in their experimental tank. Their swimming behaviour appeared normal. After several hours for recovery, required for the entire disappearance of the stress 
caused by the antibiotic bath, the sea basses' responses to the three stimulations by the water jet were recorded each day until the restoration of a normal behaviour.

In order not to attribute a null response of fish to the stress produced by

manipulation, two placebo treatments were carried out, one week apart during the three weeks of recording under control conditions. This placebo treatment consisted of placing fish for $3 \mathrm{~h}$ in 10 l-tanks without any antibiotic. They were then placed back in their experimental tank and their escape responses to the water jet were recorded after several hours of recovery.

\subsection{Cadmium exposure}

To reveal the impact of cadmium exposure on the lateral line system and the consequences for escape responses, two sets of experiments with two separate groups of fish were performed for each concentration of cadmium tested. For this, after three weeks of fish response recording under control conditions, sea bass were collected and placed in a 10 1-tank of seawater to which cadmium $\left(\mathrm{Cd}\left(\mathrm{NO}_{3}\right)_{2}\right.$, Merck, cadmium standard solution $1000 \mathrm{mg} . \mathrm{l}^{-1}$ in nitric acid $0.5 \mathrm{M}$ ) was added for $4 \mathrm{~h}$ (the time needed for cadmium adsorption onto a particle, Chiffoleau et al., 1999), at two different concentrations of cadmium. The first concentration of cadmium tested was $0.5 \mu \mathrm{g} .1^{-1}$, which represents the maximal cadmium concentration encountered in contaminated estuaries such as the Gironde, Scheldte or Hudson estuaries (Klinkhammer and Bender, 1981; Valenta et al., 1986; Elbaz-Poulichet et al., 1987; Boutier et al., 1989; Cossa and Lassus, 1989; Jouanneau et al., 1990). The second, high cadmium concentration $\left(5 \mu \mathrm{g} .1^{-1}\right)$ used, represents ten times the concentration found in highly polluted estuarine areas. Fish were then placed back in their experimental tank. Their swimming behaviour was normal. After several hours for recovery, required for the entire disappearance 
of the stress caused by the cadmium exposure, the sea bass responses to the three daily stimulations by the water jet were recorded, until the restoration of a normal behaviour. As in the antibiotic bath treatment, to evaluate the stress caused by the manipulation, two placebo treatments (four-hour baths in seawater without cadmium) were performed one week apart during the three weeks of recording under control conditions.

In addition, to test for the possibility that acid exposure alone may have a behavioural effect (from the nitric acid present in the cadmium standard solution), untreated fish were tested after exposure to dilute nitric acid. For this, fish from each set of experiments were placed for $4 \mathrm{~h}$ in seawater to which was added nitric acid at the same concentration as that during cadmium exposure (i.e. $2.5 \mu \mathrm{M}$ ). No behavioural modification was observed in sea bass after nitric acid exposure.

All aquaria and other materials in contact with metal ions were carefully decontaminated with acid (3.5\% nitric acid, Merck $+5 \%$ fuming hydrochloric acid, Merck) for 24 hours and were then copiously rinsed with distilled water before any new use.

\subsection{Checking lateral line system tissue status}

For each set of experiments, to verify the tissue status of superficial and canal lateral line system neuromasts in sea bass after antibiotic treatment and cadmium exposure, two treated fish were collected: the one, 48 hours after treatment or exposure and the other, at the end of the experiment (after return to baseline behaviour). The neuromast tissue status of treated fish was compared with that of a control fish collected at the end of the three weeks of recording under control conditions. Prior to sacrifice, collected fish were anaesthetised with 75 mg..$^{-1}$ MS-222 (3-aminobenzoic acid ethyl, Sigma) for about 15 minutes. Their entire trunk lateral line mechanoreceptors were then sampled. They consist of a single row of 
modified scales, differing from the others by the presence of superficial neuromasts and the canal tube containing canal neuromasts, running within the mid-section of each flank from the operculum to the tail (Faucher et al., 2003). Tissue samples were fixed in $4 \%$ glutaraldehyde (Fisher Scientific Labosi) in sodium cacodylate buffer (0.4 M, pH 7.2) and dehydrated in graded acetone concentrations and critical point-dried using liquid $\mathrm{CO}_{2}$ (BALTEC CPD 030). They were then mounted on brass supports and sputter-coated with gold (Cressington Sputter Coat). Observations were performed with a JEOL JSM-5410LV scanning electron microscope.

\subsection{Statistical analyses}

To estimate damage caused by cadmium to both types of neuromasts, the average number of superficial and canal neuromasts observed per scale was calculated. Data obtained were then compared between fish exposed to cadmium and control fish using non-parametric statistical tests which values were noted: $\mathrm{H}$ for Kruskal-Wallis and $\mathrm{U}$ for Mann-Whitney.

Behavioural responses to water jet stimulations were first analysed by set of experiment. Several variables were defined:

i: the number of the set of the experiment considered $(1,2$ or 3 for antibiotic treatment and 1 or 2 for cadmium exposure), $\mathrm{j}$ : the number of the daily stimulation performed $(1,2$ or 3$)$, $\mathrm{k}$ : the number of the day considered (from -21 to +33 ), $r$ : the binary value of each response ( 0 for a null response and 1 for a positive response), 

3), $100 \%)$ experiments combined. the statistical software XISTAT-Pro 6.0. The level of significance was set at $\mathrm{p}<0.05$. 


\section{Results}
3.1. Consequences of lateral line system inactivation by antibiotics on the fish responses to the water jet

\subsubsection{Checking lateral line system tissue status}

For each set of experiments, three specimens of sea bass were collected to observe the tissue status of their lateral line system neuromasts: a control fish at the end of the three weeks of recording under control conditions and two fish treated with antibiotics, 48 hours after treatment and at the end of the experiment, respectively.

Compared with superficial and canal neuromasts of control fish (fig. 2 A, B), the majority of both types of neuromasts of treated fish, collected 48 hours after antibiotic treatment, displayed significant damage (fig. 2 C, D). Their cupulae were destroyed more frequently than for control fish and their sensory macula hair bundles were either disorganised or totally destroyed (fig. 2 D). On the other hand, treated fish collected at the end of experiment showed an intact lateral line system: their superficial and canal neuromasts were similar to those observed in control fish (fig. 2 E, F).

\subsubsection{Impact of lateral line system inactivation on sea bass escape response}

Figure 3 indicates the average percentages of positive responses, $\overline{\mathrm{P}_{\mathrm{k}}}$, obtained during the whole duration of the experiment (three sets of experiments). During the first three weeks (control recording), water jet stimulations mainly generated positive responses: sea bass swam away in $97.77 \pm 5.61 \%(n=28)$ of cases. Neither of the placebo treatments modified fish 
response percentages. At day 0 , that is the day of antibiotic treatment, fish displayed only $44.44 \pm 38.39 \%(n=3)$ of positive responses to stimulations. This percentage is significantly different from that recorded in control conditions $\left(\chi^{2}=33.623, \mathrm{p}<0.0001\right)$. The percentage of positive responses to stimulations progressively decreased until it reached $8.34 \pm 11.79 \%$ $(n=3)$ the $10^{\text {th }}$ day after treatment. Between the $10^{\text {th }}$ and the $25^{\text {th }}$ day after treatment, the behaviour restoration rate was about $4 \%$ per day. From the $25^{\text {th }}$ day after treatment, sea bass started to positively respond again to stimulations in $83.33 \pm 23.57 \%(n=3)$. From this day, the positive response percentage was not significantly different from that recorded in control conditions $\left(97.77 \pm 5.61 \%, \mathrm{n}=28, \chi^{2}=2.291, \mathrm{p}=0.13\right)$

\subsection{Consequences of cadmium exposure on sea bass lateral line system and on the fish responses to the water jet}

\subsubsection{Cadmium exposure at the concentration of $0.5 \mu \mathrm{g} . \mathrm{l}^{-1}$}

\subsubsection{Checking lateral line system tissue status after cadmium exposure}

After exposure of fish to low cadmium concentration $\left(0.5 \mu \mathrm{g} .1^{-1}\right)$, the tissue status of neuromasts was observed 48 hours and one month after exposure, and compared with that of control fish neuromasts (fig. 4). In sea bass exposed to cadmium at $0.5 \mu \mathrm{g} . \mathrm{l}^{-1}$, superficial and canal neuromasts were similar to those observed in control fish (fig. 4 A, B), 48 hours (fig. 4 C, D) or one month (fig. 4 E, F) after cadmium exposure. Considering the number of neuromasts observed per scale, only one canal neuromast was observed per scale in control fish $(\mathrm{n}=21)$, in fish 48 hours $(\mathrm{n}=11)$ and also in fish one month $(\mathrm{n}=15)$ after cadmium exposure. For superficial neuromasts, control fish possessed $1.43 \pm 0.87 \%(\mathrm{n}=40)$ per scale, 
compared to $1.22 \pm 0.88 \%(\mathrm{n}=12)$ in fish 48 hours after exposure and $1.00 \pm 0.95 \%(\mathrm{n}=$ 12) in fish one month after cadmium exposure. A Kruskal-Wallis test indicated that these numbers of superficial neuromasts per scale were not significantly different $(H=0.291, p=$ $0.865)$.

\subsubsection{Impact of cadmium exposure at $0.5 \mu \mathrm{g} . \mathrm{l}^{-1}$ on sea bass escape response}

The average positive response percentages of sea bass faced with water jet were calculated before and after $0.5 \mu \mathrm{g} .1^{-1}$ cadmium exposure (fig. 5). During the three weeks of recording under control conditions, sea bass responded positively at $98.41 \pm 4.95 \%(n=42)$. Neither of the placebo treatments modified the percent positive responses. The day of cadmium exposure and during the three following weeks, sea bass displayed no behavioural difference: they went on responding positively at $95.16 \pm 9.79 \%(n=41)$ of stimulations. A $\chi^{2}$-test indicated that these two percentages, before and after low concentration cadmium exposure, were not significantly different $\left(\chi^{2}=2.464, \mathrm{p}=0.116\right)$.

\subsubsection{Cadmium exposure at the concentration of $5 \mu \mathrm{g} . \mathrm{l}^{-1}$}

\subsubsection{Checking lateral line system tissue status after cadmium exposure}

The tissue status of sea bass lateral line system neuromasts was observed 48 hours and one month after exposure to $5 \mu \mathrm{g} . \mathrm{l}^{-1}$ cadmium. Figure 6 illustrates the tissue status of both types of lateral line system neuromasts of the control fish and of fish after cadmium exposure. In control fish, both types of neuromasts had intact sensory maculae: hair bundles of 
subjacent hair cells were well developed (fig. 6 A, B). On the 24 observed scales from the control fish, the average number of superficial neuromasts was of $0.79 \pm 0.98 \%(\mathrm{n}=19)$ and $1.00 \pm 0.00 \%(\mathrm{n}=7)$ canal neuromasts per scale. In contrast, on the 30 scales observed 48 hours after cadmium exposure, all superficial and canal neuromasts were entirely destroyed: no hair bundles were seen on the sensory maculae (fig. 6 C, D). In addition, the average number of both types of neuromasts on these scales was relatively low: $0.58 \pm 0.69 \%$ ( $\mathrm{n}=$ 19) superficial neuromast and $0.44 \pm 0.51 \%(\mathrm{n}=16)$ canal neuromast per scale. As these numbers indicate, some canal neuromasts were entirely destroyed and therefore not visible. A Mann-Whitney test showed that the difference observed in the average number of superficial neuromasts per scale in control fish and fish observed 48 hours after cadmium exposure, was not significant $(\mathrm{U}=195.000, \mathrm{p}=0.321, \mathrm{n}=28)$. In contrast, for canal neuromasts, the average number observed per scale was significantly lower in fish 48 hours after cadmium exposure than in control fish $(\mathrm{U}=87.500, \mathrm{p}=0.006, \mathrm{n}=23)$.

Fish scales observed one month after cadmium exposure (at $5 \mu \mathrm{g} .1^{-1}$ ) showed intact neuromasts of each type (fig. 6 E, F) compared with control fish (fig. 6 A, B). Their average number per scale was $1.09 \pm 0.85 \%(n=23)$ superficial neuromast compared to $1.00 \pm 0.00 \%$ $(n=14)$ canal neuromast. The average number of superficial neuromasts per scale was significantly higher than that obtained 48 hours after cadmium exposure $(\mathrm{U}=145.000, \mathrm{p}=$ $0.023, \mathrm{n}=42)$ but was not significantly different from that calculated in control fish $(\mathrm{U}=$ $172.500, p=0.110, n=42$ ). For canal neuromasts, results were the same as those observed in control fish and were significantly higher than those obtained in fish 48 hours after cadmium exposure $(\mathrm{U}=49.000, \mathrm{p}<0.0001, \mathrm{n}=30)$.

\subsubsection{Impact of cadmium exposure at $5 \mu \mathrm{g} . l^{-1}$ on sea bass escape response}


The average positive response percentages recorded during the two sets of experiments from fish exposed to this high concentration of cadmium is represented in figure 7.

Before cadmium exposure, sea bass mainly responded positively: they swam away after stimulation by the water jet in $95.93 \pm 9.10 \%(n=41)$ of cases. The two placebo treatments realised did not generate any behavioural modification in sea bass. The day of cadmium exposure, the positive response percentage fell significantly $\left(\chi^{2}=24.562, \mathrm{p}<\right.$ 0.0001): sea bass responded positively in only $41.67 \pm 35.36 \%(n=2)$ of stimulations. This percentage progressively decreased until it reached $0.00 \pm 0.00 \%(\mathrm{n}=2)$ the $5^{\text {th }}$ day after cadmium exposure. Then, from this day, sea bass tended to detect the water jet progressively more frequently: their positive response percentage increased progressively by about $4 \%$ per day. From the $21^{\text {st }}$ day after cadmium exposure, the average percentage of positive responses recorded $(86.74 \pm 20.82 \%, \mathrm{n}=11)$ was not significantly different from that recorded under control conditions $\left(95.93 \pm 9.10 \%, \mathrm{n}=41, \chi^{2}=2.876, \mathrm{p}=0.090\right)$.

\section{Discussion}

In fish, the detection of a water current is a lateral-system-specific stimulus. Water flow from many different directions is mainly detected by superficial neuromasts located in the anterior part of the head (Janssen et al., 1987; Voigt et al., 2000). In this study, when sea bass possessed an intact lateral line system, sudden water-jet stimulation involved an instantaneous and effective escape, of the "C-start" type, in more than $97 \%$ of cases. Combining all recordings under control conditions, a small percentage of failures to respond (less than $3 \%$ ) was observed. However, in previous behavioural experiments, a larger percentage of failures in fish responses have been reported: for example, Blaxter and Fuiman 
(1989) showed that herring, cod and plaice larvae displayed an effective escape reaction when a probe approached with an error (failures to respond) percentage of less than $20 \%$.

Compared with this result, the percentage of failures to respond obtained in our experiments seems practically negligible. It can be attributed to stimulations realised asynchronously according to the crossing of fish in the close vicinity of the stimulation system: the water jet might be applied when the fish was already out of reach. In addition, daily stimulations may have caused a certain level of habituation.

After antibiotic treatment, fish reacted to only about $40 \%$ of stimulations and this percentage progressively fell to $8 \%$ ten days after treatment. This result indicates that at least some superficial and canal neuromasts were not functional. Indeed, water jets injected under the surface when fish swam in front of the stimulation system did not generate any marked escape behaviour. This particular fish behaviour can be attributed to their non-functional lateral line system. Blaxter and Fuiman (1989) have already observed the disappearance of escape behaviour in herring, cod and plaice larvae after destruction of their superficial neuromasts by high-concentration streptomycin or as a result of turbulence destroying their cupulae. These experiments confirm the necessity for fish to have a functional lateral line system to respond to hydrodynamic stimuli (Janssen and Corcoran, 1993). Blaxter and Fuiman (1989) may go too far in suggesting that the approach of a predator or any organism is detected by superficial neuromasts in relation with Mauthner cells. In contrast, Abdel-Latif et al. (1990) and Bleckmann (2000) showed that detection of hydrodynamic stimuli is mediated by canal neuromasts. These two divergent hypotheses could be explained by the fact that hydrodynamic stimuli are expressed as two components: the water flow velocity to which superficial neuromasts are sensitive, and the flow acceleration at the beginning and at the end of a water current, detected by canal neuromasts (Denton and Gray, 1989; Voigt et al., 2000). 
After antibiotic treatment damaged their lateral line system, sea bass progressively recovered normal behaviour: the positive response percentage to stimulations gradually increased, at the rate of $4 \%$ per day, eventually recovering to baseline levels. This progressive behavioural recovery, observed over about one month, can be compared with the regeneration of their lateral line system. Indeed, scanning electron microscopy observations showed that both types of neuromasts sampled on sea bass one month after treatment were by then intact. Apart from the consistent absence of their cupulae, which could be attributed to a manipulation artefact, their maculae possessed hair bundles in which tissue status and organisation were similar to those observed in control fish.

The stimulation system adjusted in this study was thus really specific to the lateral line system, since the inactivation of this sensory system resulted in a non-response of fish to the water jet. In addition, a restoration of their escape behaviour was observed after one month, the time needed for the regeneration of both types of lateral line system neuromasts. The alteration of fish mechanosensory abilities by metal ions has been reviewed by Atchison et al. (1987). Nevertheless, the impact of a cadmium exposure on fish behaviour had been shown mainly on freshwater fish. Many behavioural consequences have been described: swimming alterations (Yorulmazlar and Gül, 2003), intraspecific interactions (Sloman et al., 2003a, b; Tilton et al., 2003), predator / prey interactions (Sullivan et al., 1978; Scherer et al., 1997; Scott et al., 2003) and avoidance responses (McNicol et al., 1996, 1999). One study also pointed out that cadmium could induce in freshwater fish sensory deficiencies in both olfaction and in the lateral line system (Baker and Montgomery, 2001). However, apart from this, very few studies have demonstrated the impact of cadmium on seawater fish behaviour. For example, in the catfish Ictalurus nebulosus, $40 \mu \mathrm{g} .1^{-1}$ cadmium deteriorated electroorientation performance by blocking calcium-channels in the basal membrane of electroreceptors (Neuman et al., 1991). In addition, the white seabass Lates calcarifer and the 
flounder Pleuronectes flesus presented erratic swimming in response to an acute cadmium exposure at high concentration (10 mg. $\mathrm{l}^{-1}$ ) (Larsson et al., 1976; Tophon et al., 2003). Associated with this abnormal behaviour, the white sea bass exhibited an excessive mucus production on the opercular surface, hyperventilation and a lower feeding rate (Tophon et al., 2003).

In this study, under control conditions, sea bass performed immediate and effective responses, of the C-start type, in more than $95 \%$ of stimulations caused by the sudden water jet. In the overwhelming majority of cases, these positive responses were made when the lateral line system of fish considered was intact. Indeed, observations made with a scanning electron microscope showed that before cadmium exposure, both types of lateral line system neuromasts were normal. In contrast, after a high-concentration acute cadmium exposure (5 $\mu \mathrm{g} . \mathrm{l}^{-1}$ ), sea bass did not respond to the water jet: they seemed not to detect hydrodynamic stimulations. This result is consistent with the destruction of both types of lateral line system neuromasts observed 48 hours after cadmium exposure: their maculae were entirely destroyed. In addition, treated sea bass possessed fewer superficial and canal neuromasts than control fish: although this difference was not significant for superficial neuromasts, it was highly significant for canal neuromasts. As suggested by Verbost et al. $(1987,1988)$ at the time of their studies on the inhibitor effect of cadmium on calcium transport in trout gills, cadmium ions might have been in competition with calcium ions, although the latter are far more abundant in seawater. As observed for gills, cadmium and calcium ions are mutually antagonistic in fixation processes on sites located at the level of the $\mathrm{Ca}^{2+}$-ATPase pump of the baso-lateral membrane of neuromast hair cells. The result of this seems to be a blockage of calcium transport in cells associated with their obvious degeneration. Consequently, when exposed to high-concentration cadmium, fish might not be in a position to perceive hydrodynamic stimuli relating to the approach of a predator, a prey, a congener or fishing 
gear. Its survival in an environment contaminated with metal ions would thus be strongly compromised. Yet, the sea bass lateral line system possesses a great regenerative potential. Indeed, about five days after metal ion exposure was stopped, fish showed a progressive restoration of their escape behaviour. After 21 days, the level of C-start responses was equivalent to that recorded under control conditions. We can thus conclude that this is the period needed for the lateral line system to regenerate itself at a sufficient rate to allow detection of hydrodynamic stimuli. Indeed, the tissue status of both types of neuromasts observed by scanning electron microscopy one month after acute exposure to highconcentration cadmium was similar to that of neuromasts observed in control fish at the beginning of the experiment. Compared to control fish, neuromast number was also equivalent. Thus, it can be suggested not only that partially damaged superficial neuromasts were restructured to become functional again but also that those which had been entirely destroyed and were thus not visible, had entirely regenerated.

In contrast, when fish were exposed to cadmium at a concentration close to that recorded in natural polluted environments $\left(0.5 \mu \mathrm{g} . \mathrm{l}^{-1}\right)$, they did not present any behavioural modification. They continued to respond positively with C-start escape behaviour in response to the water jet. We can thus conclude that the concentration chosen and the cadmium exposure time were lower than the threshold necessary for inhibition of the sea bass lateral line system. Examination by SEM of superficial and canal tissue status after such an exposure to cadmium corroborates this hypothesis. Both types of neuromasts observed in sea bass after exposure were similar to those observed under control conditions. This indicates that the cadmium did not modify behaviour even though stimuli applied in this study were relatively strong, most likely more intense than signals received by fish when a predator or a prey approaches. In this way, if sea bass exposed to this low concentration of cadmium correctly responded to strong stimuli, it is not resolved what would happen in a natural environment 
faced with lower intensity stimuli. Even if the tissue aspect of their neuromasts remained normal, we can venture the hypothesis of a lower efficiency in the detection of potential predator or prey in natural environments after exposure to cadmium. To confirm or refute this hypothesis, the lateral line system response to variable intensity stimuli could be tested by varying the current velocity of stimulations, attempting to approach as far as possible the stimuli generated by moving prey. On the other hand, in natural environments, sea bass are permanently exposed to this concentration of cadmium dissolved in the water column. The effects of such chronic exposure to cadmium might be greater than those suggested by our experiments using only acute exposure. The threshold cadmium concentration for lateralsystem sensory deterioration now requires investigation for chronic exposure.

\section{Acknowledgements}

We wish to thank Ian Jenkinson for improving our English writing. We also thank especially one of the reviewers for its detailed suggestions and clarifications to improve the manuscript. This study was supported by a grant (K.F.) from the Conseil Général de la Charente Maritime. Thanks to Vendée Aquaculture for donation of the animals. We would also like to thank the Centre Commun d'Analyses (CCA), Universite de La Rochelle, for allowing the use of a scanning electron microscope.

\section{References}

Abboud, J.A., Coombs, S., 2000. Mechanosensory-based orientation to elevated prey by a benthic fish. Mar. Fresh. Behav. Physiol. 33, 261-279. 
Abdel-Latif, H., Hassan, E., Campenhausen von, C., 1990. Sensory performance of blind mexican cave fish after destruction of the canal neuromasts. Naturwissenschaften. 77, 237-239.

Al-Yousuf, M.H., El-Shahawi, M.S., Al-Ghais, S.M., 2000. Trace metals in liver, skin and muscle of Lethrinus lentjan fish species in relation to body length and sex. Sci. Total Environ. 256, 87-94.

Atchinson, G.J., Henry, M.G., Sandheinrich, M.B., 1987. Effects of metals on fish behavior: a review. Environ. Biol. Fish. 18(1), 11-25.

Baker, C.F., Montgomery, J.C., 1999a. The sensory basis of rheotaxis in the blind mexican cave fish, Astyanax fasciatus. J. Comp. Physiol. A. 184, 519-527.

Baker, C.F., Montgomery, J.C., 1999b. Lateral line mediated rheotaxis in the antarctic fish Pagothenia borchgrevinki. Polar Biol. 21, 305-309.

Baker, C.F., Montgomery, J.C., 2001. Sensory deficit induced by cadmium in banded kokopu, Galaxias fasciatus, juveniles. Environ. Biol. Fish. 62, 455-464.

Blaxter, J.H.S., Hoss, D.E., 1981. Startle response in herring: the effect of sound stimulus frequency, size of fish and selective interference with the acoustico-lateralis system. J. Mar. Biol. Ass. U.K. 61, 871-879.

Blaxter, J.H.S., Batty, R.S., 1985. Herring behaviour in the dark: responses to stationary and continuously vibrating obstacles. J. Mar. Biol. Ass. U.K. 65, 1031-1049.

Blaxter, J.H.S., Fuiman, L.A., 1989. Function of the free neuromasts of marine teleost larvae. In: Coombs, S., Görner, P., Münz, H., The mechanosensory lateral line, neurobiology and evolution. New York, Springer Verlag, pp. 481-499.

Bleckmann, H., 1993. Role of the lateral line in fish behaviour. In: Pitcher T. J., Behaviour of teleost fishes $2^{\text {nd }}$ ed. London, Chapman and Hall, pp. 201-246.

Bleckmann, H., 2000. Hydrodynamic stimuli and the fish lateral line. Nature. 408, 51-52. 
Boutier, B., Chiffoleau, J.-F., Jouanneau, J.M., Latouche, C., Phillips, I., 1989. La contamination de la Gironde par le cadmium: origine, extension, importance. Rapports Scientifiques et Techniques de l'IFREMER. 14, 105 pp, Brest.

Bryan, G.W., 1979. Bioaccumulation of marine pollutants. Phil. Trans. R. Soc. Lond. B286, 483-505.

Canfield, J.G., Rose, G.J., 1996. Hierarchical sensory guidance of Mauthner-mediated escape responses in goldfish (Carassius auratus) and cichlids (Haplochromis burtoni). Brain Behav. Evol. 48, 137-156.

Carlson, R.W., Bradbury, S.P., Drummond, R.A., Hammermeister, D.E., 1998. Neurological effects on startle response and escape from predation by medaka exposed to organic chemicals. Aquat. Toxicol. 43, 51-68.

Casagrand, J.L., Guzik, A.L., Eaton, R.C., 1999. Mauthner and reticulospinal responses to the onset of acoustic pressure and acceleration stimuli. J. Neurophysiol. 82, 1422-1437.

Cattani, O., Serra, R., Isani, G., Raggi, G., Cortesi, P., Carpene, E., 1996. Correlation between metallothionein and energy metabolism in sea bass, Dicentrarchus labrax, exposed to cadmium. Comp. Biochem. Physiol. 113C(2), 193-199.

Chiffoleau, J.-F., Gonzalez, J.-L., Miramand, P., Thouvenin, B., Guyot, T., 1999. Le cadmium: comportement d'un contaminant métallique en estuaire. Programme scientifique Seine-Aval. 10, $39 \mathrm{pp}$.

Coombs, S., 1999. Signal detection theory, lateral-line excitation patterns and prey capture nehaviour of mottled sculpin. Anim. Behav. 58, 421-430.

Coombs, S., Janssen, J., Webb, J.F., 1989. Diversity of lateral systems: evolutionary and functional considerations. In: Atema, J., Fay, R.R., Popper, A.N., Tavolga, W.N., Sensory Biology of Aquatic Animals. New York, Springer Verlag, pp. 553-593. 
Coombs, S., Braun, C.B., Donovan, B., 2001. The orienting response of lake michigan mottled sculpin id mediated by canal neuromasts. J. Exp. Biol. 204, 337-348.

Cossa, D., Lassus, P., 1989. Le cadmium en milieu marin, biogéochimie et écotoxicologie. Rapports scientifiques et techniques de l'IFREMER. 16, $111 \mathrm{pp}$.

Denton, E.J., Gray, J.A.B., 1989. Some observations on the forces acting on neuromasts in fish lateral line canals. In: Coombs, S., Görner, P., Münz, H., The mechanosensory lateral line, neurobiology and evolution. New York, Springer Verlag, pp. 229-246.

Dijkgraaf, S., 1962. The functioning and significance of the lateral-line organs. Biol. Rev. 38, 51-105.

Eaton, R.C., Lee, R.K.K., Foreman, M.B., 2001. The Mauthner cell and other identified neurons of the brainstem escape network of fish. Prog. Neurobiol. 63, 467-485.

Eisler, R., Hennekey, R.J., 1977. Acute toxicities of $\mathrm{Cd}^{2+}, \mathrm{Cr}^{6+}, \mathrm{Hg}^{2+}, \mathrm{Ni}^{2+}$ and $\mathrm{Zn}^{2+}$ to estuarine macrofauna. Arch. Environ. Contam. Toxicol. 6, 315-323.

Elbaz-Poulichet, F., Martin, J.M., Huang, W.W., Zhu, J.X., 1987. Dissolved Cd behaviour in some selected french and chinese estuaries. Consequences on Cd supply to the ocean Mar. Chem. 22(2-4), 125-136.

Enger, P.S., Kalmijn, A.J., Sand, O., 1989. Behavioral investigations on the functions of the lateral line and inner ear in predation. In: Coombs, S., Görner, P., Münz, H., The mechanosensory lateral line, neurobiology and evolution. New York, Springer Verlag, pp. 575-587.

Faucher, K, Aubert, A, Lagardère, J.-P., 2003. Spatial distribution and morphological characteristics of the trunk lateral line neuromasts of the sea bass (Dicentrarchus labrax, L.; Teleostei, Serranidae). Brain Behav. Evol. 62, 223-232.

Forge, A., Schacht, J., 2000. Aminoglycoside antibiotics. Audiol. Neurootol. 5, 3-22. 
Friberg, L., Piscator, M., Nordberg, G.F., Kjellstrom, T., 1974. Cadmium in the environment. $2^{\text {nd }}$ edition, CRC Press, New-York.

Higgs, D.M., Fuiman, L.A., 1996. Ontogeny of visual and mechanosensory structure and function in atlantic menhaden Brevoortia tyrannus. J. Exp. Biol. 199, 2619-2629.

Hoekstra, D., Janssen, J., 1986. Lateral line receptivity in the mottled sculpin (Cottus bairdi). Copeia 1, 91-96.

Hudspeth, A.J., 1983. Mechanoelectrical transduction by hair cells in the acousticolateralis sensory system. Annu. Rev. Neurosci. 6, 187-215.

Hudspeth, A.J., Corey, D.P., 1977. Sensitivity, polarity, and conductance change in the response of vertebrate hair cells to controlled mechanical stimuli. Proc. Natl. Acad. Sci. U.S.A. 74(6), 2407-2411.

Janssen, J., 2000. Toxicity of Co2+: implications for lateral line studies. J. Comp. Physiol. A. $186,957-960$.

Janssen, J., Corcoran, J., 1993. Lateral line stimuli can override vision to determine sunfish strike trajectory. J. Exp. Biol. 176, 299-305.

Janssen, J., Coombs, S., Hoekstra, D., Platt, C., 1987. Anatomy and differential growth of the lateral line system of the mottled sculpin, Cottus bairdi (Scorpaeniformes: Cottidae). Brain Behav. Evol. 30, 210-229.

Janssen, J., Jones, W.R., Whang, A., Oshel, P.E., 1995. Use of the lateral line in particulate feeding in the dark by juvenile alewife (Alosa Pseudoharengus). Can. J. Fish Aquat. Sci. 52, 358-363.

Janssen, J.V., Sideleva, V., Biga, H., 1999. Use of the lateral line for feeding in two Lake Baikal sculpins. J. Fish Biol. 54, 404-416.

Jørgensen, F., 1984. Influence of $\mathrm{Ca}^{2+}$ on the voltage-dependent mechanosensitivity of the hair cells in the latera line organs of Xenopus laevis. Acta Physiol. Scand. 120, 481-488. 
Jouanneau, J.M., Boutier, B., Chiffoleau, J.F., Latouche, C., Phillips, I., 1990. Cadmium in the Gironde fluvioestuarine system: behaviour and flow. Sci. Total Environ. 97/98, 465479.

Karlsen, H.E., Sand, O., 1987. Selective and reversible blocking of the lateral line in freshwater fish. J. Exp. Biol. 133, 249-262.

Kaus, S., 1987. The effect of aminoglycoside antibiotics on the lateral line organ of Aplocheilus lineatus (Cyprinodontidae). Acta Oto-laryng. (Stockh) 103, 291-298.

Klinkhammer, G.P., Bender, M.L., 1981. Trace metal distributions in the Hudson River estuary. Est. Coast. Shelf Sci. 12, 629-643.

Kroese, A.B.A., Das, A., Hudspeth, A.J., 1989. Blockage of the transduction channels of hair cells in the bull frog's sacculus by aminoglycoside antibiotics. Hear. Res. 37, 203-218.

Larsson, A., Bengtsson, B.E., Svanberg, O., 1976. Some haematological and biochemical effects of cadmium on fish. In: Lockwood, A.P.M. (Ed.), Effects of pollutants on aquatic organisms. Soc. Exp. Biol. Seminar. Ser. 2, 35-45.

Liang, X.F., Liu, J.K., Huang, B.Y., 1998. The role of sense organs in the feeding behaviour of chinese perch. J. Fish Biol. 52, 1058-1067.

Matsuura, S., Ikeda, K., Furukawa, T., 1971. Effects of streptomycin, kanamycin, quinine, and other drugs on the microphonic potentials of goldfish sacculus. Jpn. J. Physiol. 21, 579-590.

McNicol, R.E., Bégout-Anras, M.L., Scherer, E., 1999. Influence of light preferences on the avoidance responses of lake whitefish, Coregonus clupeaformis, to cadmium. Environ. Biol. Fish. 55, 295-306.

McNicol, R.E., Scherer, E., Gee, J.H., 1996. Shoaling enhances cadmium avoidance by lake whitefish, Coregonus clupeaformis. Environ. Biol. Fish. 47, 311-319. 
Meyers, J.R., Copanas, E.H., Zottoli, S.J., 1998. Comparison of fast startle responses between two elongate bony fish with an anguilliform type of locomotion and the implications for the underlying neuronal basis of escape behavior. Brain Behav. Evol. 52, 7-22.

Miramand, P., Fichet, D., Bentley, D., Guary, J.C., Caurant, F., 1998. Concentrations en métaux lourds $(\mathrm{Cd}, \mathrm{Cu}, \mathrm{Pb}, \mathrm{Zn})$ observées le long du gradient de salinité dans le réseau trophique pélagique de l'estuaire de la Seine. C. r. Acad. Sci., Série III. 327, 259-264.

Montgomery, J.C., 1989. Lateral detection of planktonic prey. In: Coombs, S., Görner, P., Münz, H., The mechanosensory lateral line, neurobiology and evolution. New York, Springer Verlag, pp. 561-573.

Montgomery, J.C., Milton, R.C., 1993. Use of the lateral line for feeding in the torrentfish (Cheimarrichthys fosteri). N. Z. J. Zool. 20, 121-125.

Montgomery, J.C., Hamilton, A.R., 1997. Sensory contributions to nocturnal prey capture in the dwarf scorpion fish (Scorpaena papillosus). Mar. Freshw. Behav. Physiol. 30, 209223.

Montgomery, J.C., Baker, C.F., Carton, A.G., 1997. The lateral line can mediate rheotaxis in fish. Nature. 389, 960-963.

Neuman, I.S.A., Rossum van, C., Bretschneider, F., Teunis, P.F.M., Peters, R.C., 1991. Biomonitoring: cadmium deteriorates electro-orientation performance in catfish. Comp. Biochem. Physiol. 100C(1-2), 259-262.

New, J.G., Alborg Fewkes, L., Khan, A.N., 2001. Strike feeding behavior in the muskellunge, Esox masquinongy: contributions of the lateral line and visual sensory systems. J. Exp. Biol. 204, 1207-1221.

Northcutt, R.G., 1997. Swimming against the current. Nature. 389, 915-916.

Partridge, B.L., 1982. The structure and function of fish schools. Sci. Am. 246(6), 114-123. 
691

692

693

694

695

696

697

698

699

700

701

702

703

704

705

706

707

708

709

710

711

712

713

714

Partridge, B.L., Pitcher, T.J., 1980. The sensory basis of fish schools: relative roles of lateral line and vision. J. Comp. Physiol. A. 135, 315-325.

Pavlov, D.S., Tyuryukov, S.N., 1993. The role of lateral-line organs and equilibrium in the behavior and orientation of the dace, Leuciscus leuciscus, in a turbulent flow. J. Ichthyol. 33(5), 45-55.

Pitcher, T.J., Partridge, B.L., Wardle, C.S., 1976. A blind fish can school. Science. 194, 963965.

Poling, K.R., Fuiman, L.A., 1997. Sensory development and concurrent behavioural changes in Atlantic croaker larvae. J. Fish Biol. 51, 402-421.

Richardson, G.P., Russell, I.J., 1991. Cochlear cultures as a model system for studying aminoglycoside induced ototoxicity. Hear. Res. 53, 293-311.

Sand, O., 1975. Effects of different ionic environments on the mechano-sensitivity of lateral line organs in the mudpuppy. J. Comp. Physiol. 102, 27-42.

Scherer, E., McNicol, R.E., Evans, R.E., 1997. Impairment of lake trout foraging by chronic exposure to cadmium: a black-box experiment. Aquat. Toxicol. 37, 1-7.

Scott, G.R., Sloman, K.A., Rouleau, C., Wood, C.M., 2003. Cadmium disrupts behavioural and physiological responses to alarm substance in juvenile rainbow trout (Oncorhyncus mykiss). J. Exp. Biol. 206, 1779-1790.

Sloman, K.A., Baker, D.W., Ho, C.G., McDonald, D.G., Wood, C.M., 2003a. The effects of trace metal exposure on agonistic encounters in juvenile rainbow trout, Oncorhynchus mykiss. Aquat. Toxicol. 63, 187-196.

Sloman, K.A., Scott, G.R., Diao, Z., Rouleau, C., Wood, C.M., McDonald, D.G., 2003b. Cadmium affects the social behaviour of rainbow trout, Oncorhynchus mykiss. Aquat. Toxicol. 65, 171-185. 
Smith, B.P., Hejtmancik, E., Camp, B.J., 1976. Acute effects of cadmium on Ictalurus punctatus (Catfish). Bull. Environ. Contam. Toxicol. 15(3), 271-277.

Song, J., Yan, H.Y., Popper, A.N., 1995. Damage and recovery of hair cells in fish canal (but not superficial) neuromasts after gentamicin exposure. Hear. Res. 91, 63-71.

Sullivan, J.F., Atchison, G.J., Kolar, D.J., McIntosh, A.W., 1978. Changes in the predatorprey behavior of fathead minnows (Pimephales promelas) and largemouth bass (Micropterus salmoides) caused by cadmium. J. Fish. Res. Board Can. 35, 446-451.

Tayal, A.K., Kaur, I., Mathur, R.P., 2000. Bioaccumulation and localization of exogenous cadmium in a teleost by electron microscopy (TEM) and its specific quantification by electron probe X-ray microanalysis (EPMA). Bioorg. Med. Chem. 8, 475-482.

Tilton, S.C., Foran, C.M., Beson, W.H., 2003. Effects of cadmium on the reproductive axis of Japanese medaka (Oryzias latipes). Comp. Biochem. Physiol. C. 136, 265-276.

Tophon, S., Kruatrachue, M., Upatham, E.S., Pokethitiyook, P., Sahaphong, S., Jaritkhuan, S., 2003. Histopathological alterations of white seabass, Lates calcarifer, in acute and subchronic cadmium exposure. Environ. Pollut. 121, 307-320.

Valenta, P., Duursma, E. K., Merks, A. G. A., Rützel, H., Nürnberg, H. W., 1986.

Distribution of $\mathrm{Cd}, \mathrm{Pb}$ and $\mathrm{Cu}$ between the dissolved and particulate phase in the Eastern Scheldt and Western Scheldt estuary. Sci. Total Environ. 53(1-2), 41-76

Verbost, P.M., Flik, G., Lock, R.A.C., Wendelaar Bonga, S.E., 1987. Cadmium inhibition of $\mathrm{Ca}^{2+}$ uptake in rainbow trout gills. Am. J. Physiol. 253, R216-R221.

Verbost, P.M., Flik, G., Lock, R.A.C., Wendelaar Bonga, S.E., 1988. Cadmium inhibits plasma membrane calcium transport. J. Membr. Biol. 102, 97-104.

Voigt, R., Carton, A.G., Montgomery, J.C., 2000. Responses of anterior lateral line afferent neurones to water flow. J. Exp. Biol. 203, 2495-2502.

Weihs, D., 1973. The mechanism of rapid starting of a slender fish. Biorheology. 10, 343-350. 
740 Wersäll, J., Flock, A., 1964. Suppression and restoration of the microphonic output from the 741 lateral line organ after local application of streptomycin. Life Sci. 3, 1151-1155.

742

Yorulmazlar, E., Gül, A., 2003. Investigation of acute toxicity of cadmium sulfate $\left(\mathrm{CdSO}_{4}\right.$. $\mathrm{H}_{2} \mathrm{O}$ ) and behavioral changes of grass carp (Ctenopharyngodon idellus Val. 1844). Chemosphere. 53, 1005-1010.

Zottoli, S.J., 1977. Correlation of the startle reflex and Mauthner cell auditory responses in unrestrained goldfish. J. Exp. Biol. 66, 243-254.

Zottoli, S.J., 1978. Comparative morphology of the Mauthner cell in fish and amphibians. In: Faber, D.S., Korn, H., Neurobiology of the Mauthner cell. Raven Press, New York, pp. $13-45$

Zottoli, S.J., Newman, B.C., Rieff, H.I., Winters, D.C., 1999. Decrease in occurrence of fast startle responses after selective Mauthner cell ablation in goldfish (Carassius auratus). J. Comp. Physiol. A. 184, 207-218. 
754 Figure 1: Sequential single frames from the overhead video system $\left(25\right.$-frames. $\left.\mathrm{s}^{-1}\right)$ illustrating the development of a positive response $(\mathrm{A}, \mathrm{B}, \mathrm{C})$ and a null response $(\mathrm{D}, \mathrm{E}, \mathrm{F})$ of fish to the water jet. The pipette injecting water is located on the left of each frame (black arrows). A, B, C. Before lateral line system inactivation, sea bass responded to water jet by bending their body into a C-like shape and accelerating their swimming to escape the danger. This entire behaviour is called a C-start response. D, E, F. After lateral line system inactivation, sea bass seemed not to detect the water jet: they remained immobile, were pushed away by the stimulus stream, or continued to swim at constant velocity.

Figure 2: Scanning electron micrographs showing the effect of antibiotic treatment on tissue status of both superficial and canal neuromasts. A, B. Intact superficial (A) and canal (B) neuromasts observed in a control fish. Superficial neuromast is still covered by its cupula (A) whereas its absence on canal neuromast reveals hair bundles (insert in B). C, D. 48 hours after treatment, superficial (C) and canal (D) neuromasts were damaged. Hair bundles present within sensory macula of canal neuromast were totally destroyed (insert in D). E, F. One month after treatment, superficial (E) and canal (F) neuromasts displayed a normal morphology. The crush appearance of the superficial neuromast cupula in $\mathrm{E}$ is due to a manipulation artefact.

\section{Figure 3: Percentages of positive C-start escape responses caused by lateral line system} stimulations over consecutive days. Day Zero on the $\mathrm{x}$-axis corresponds to the day when fish were exposed to antibiotic treatment used to inactivate their lateral line system. Before treatment, sea bass positively reacted to the water jet. In contrast, as soon as their lateral line system was inactivated, the positive response percentage quickly fell. A recovery to baseline 
escape behaviour percentages in response to jet stimulation was observed from the $25^{\text {th }}$ day after treatment. The regression formula given corresponds to the recovery function.

Figure 4: Scanning electron micrographs showing the effect of low-concentration cadmium exposure $\left(0.5 \mu \mathrm{g} .1^{-1}\right)$ on tissue status of both types of neuromasts. A, B. Intact superficial (A) and canal (B) neuromasts observed in a control fish. C, D. 48 hours after exposure, superficial (C) and canal (D) neuromasts were similar to those observed in control fish. The insert in D shows normal hair bundles in a canal neuromast. E, F. One month after exposure, superficial (E) and canal (F) neuromasts showed a normal morphology. The insert in F illustrates the normal morphology of canal neuromast hair bundles.

Figure 5: Percentages of positive C-start escape responses caused by lateral line system stimulations over consecutive days. Day Zero on the $\mathrm{x}$-axis corresponds to the day when fish were exposed to $0.5 \mu \mathrm{g} . \mathrm{l}^{-1}$ cadmium. Before and after low-concentration cadmium exposure, fish positively responded to water jet. The low-concentration cadmium exposure had no detectable impact on their percentage of escape responses.

Figure 6: Scanning electron micrographs showing the effect of high-concentration cadmium exposure $\left(5 \mu \mathrm{g} .1^{-1}\right)$ on tissue status of both types of neuromasts. A, B. Intact superficial (A) and canal (B) neuromasts observed in a control fish. Superficial neuromast is still covered by its cupula (A) whereas its absence on canal neuromast reveals hair bundles (insert in B). C, D. 48 hours after exposure, superficial (C) and canal (D) neuromasts were entirely deprived of hair bundles (inserts in C and D). E, F. One month after exposure, superficial (E) and canal (F) neuromasts appeared normal. Their hair bundles (inserts in E and F) were similar to those observed in control fish. 
804 Figure 7: Percentages of positive C-start escape responses caused by lateral line system

805

806

807 stimulations over consecutive days. Day Zero on the $\mathrm{x}$-axis corresponds to the day when fish were exposed to $5 \mu \mathrm{g} . \mathrm{l}^{-1}$ cadmium. Before cadmium exposure, the majority of sea bass positively reacted to water jet. In contrast, as soon as their lateral line system was exposed to high-concentration cadmium, the positive response percentage quickly fell. A recovery of their escape behaviour in response to water jet stimulation was observed from the $21^{\text {st }}$ day after cadmium exposure. The regression formula given corresponds to the recovery function. 2

(1)


832 A

833

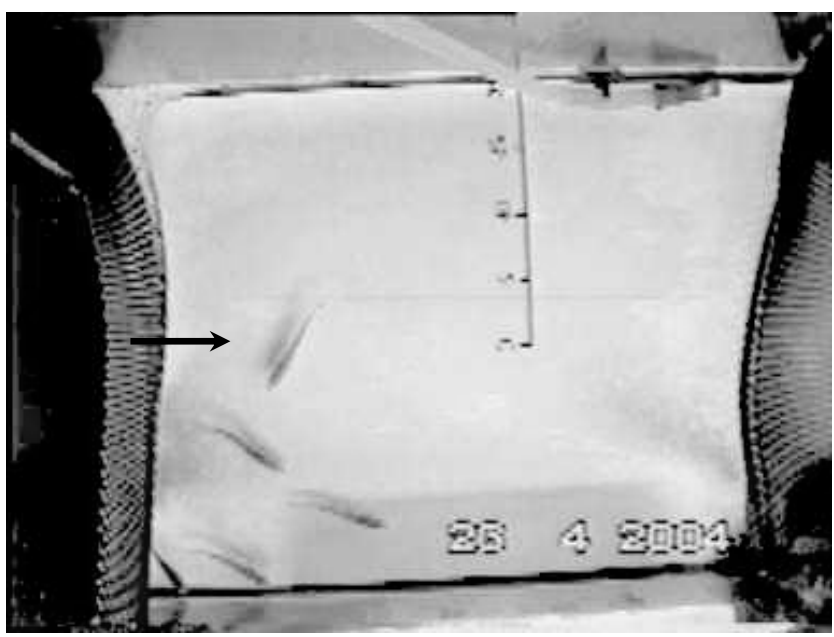

834

835

836

837

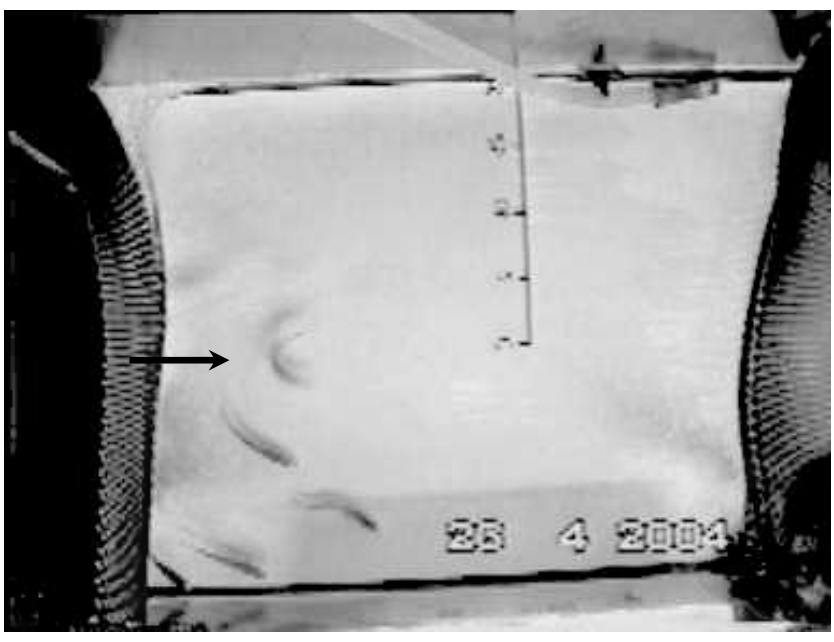

838

839

840

841

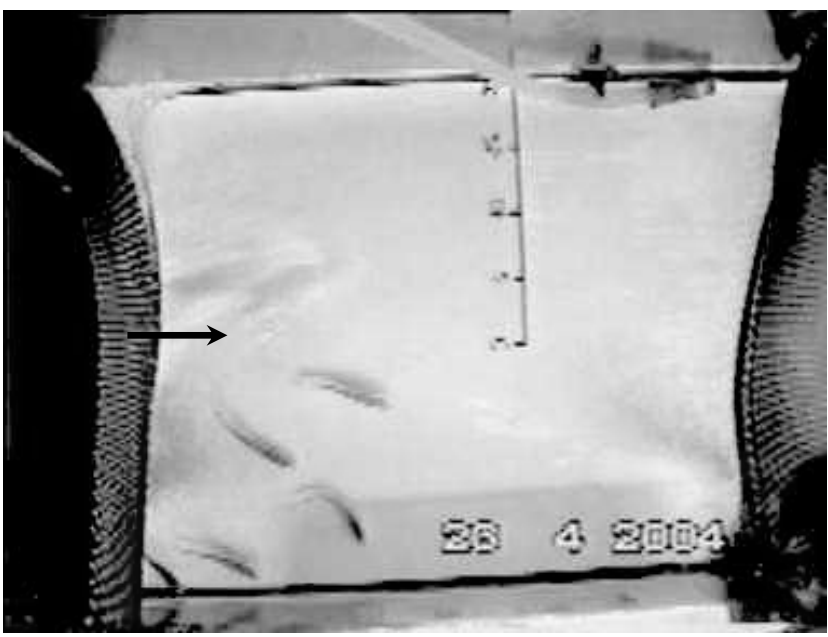

D

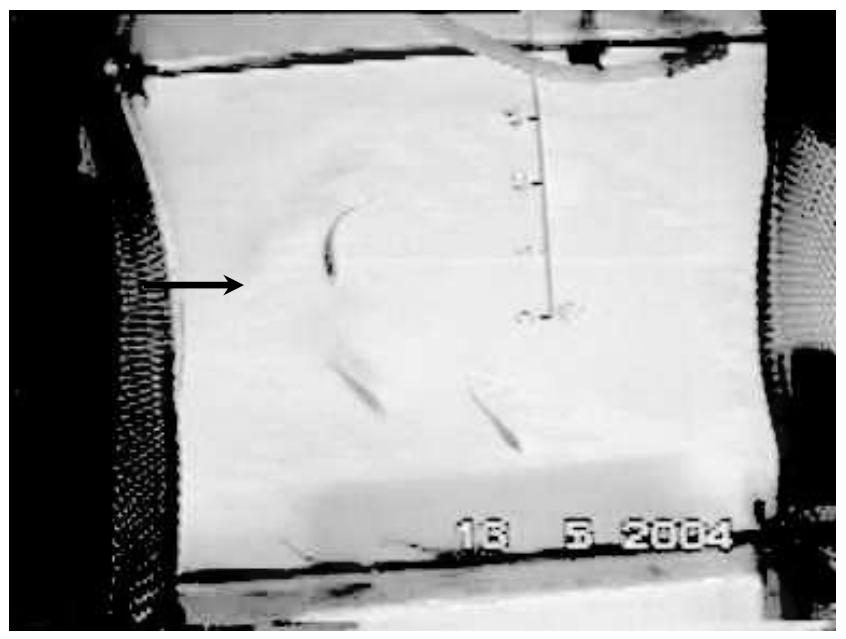

E

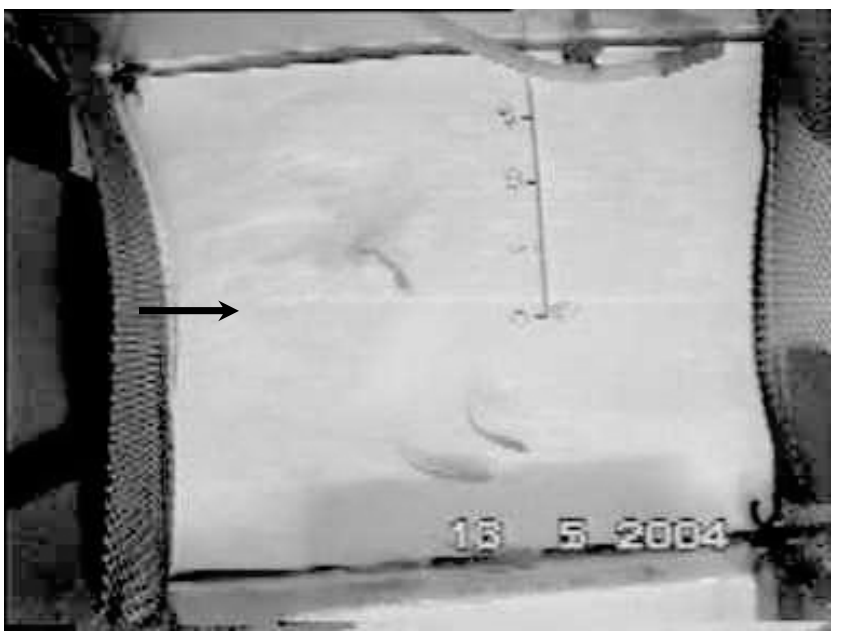

F

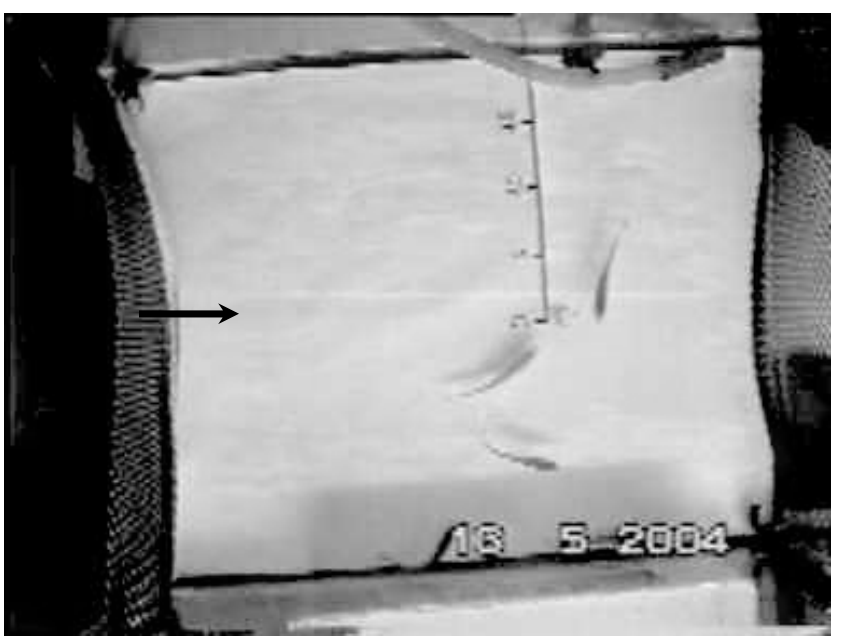


843 A

844

845

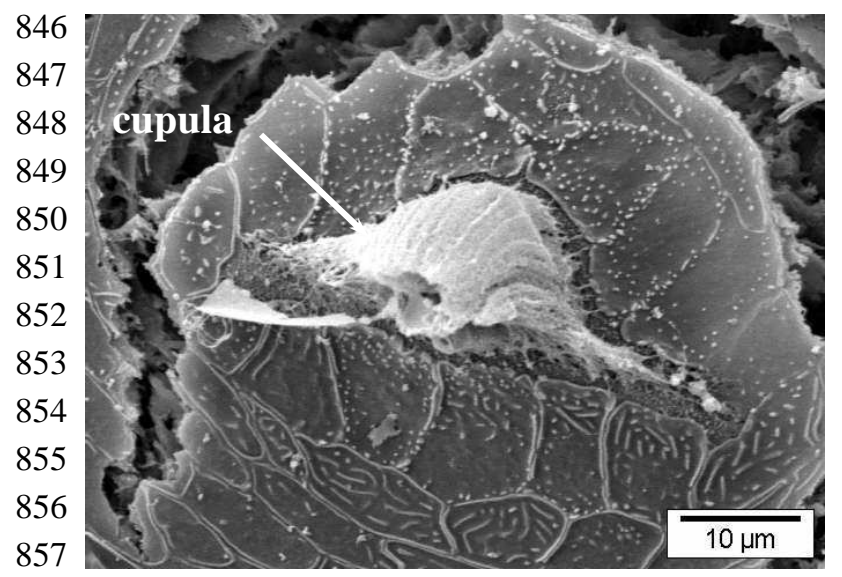

858

859 C

860

861

862

863

864

865

866

867

868

869

870

871

872

873

874

875

876 E

877

878

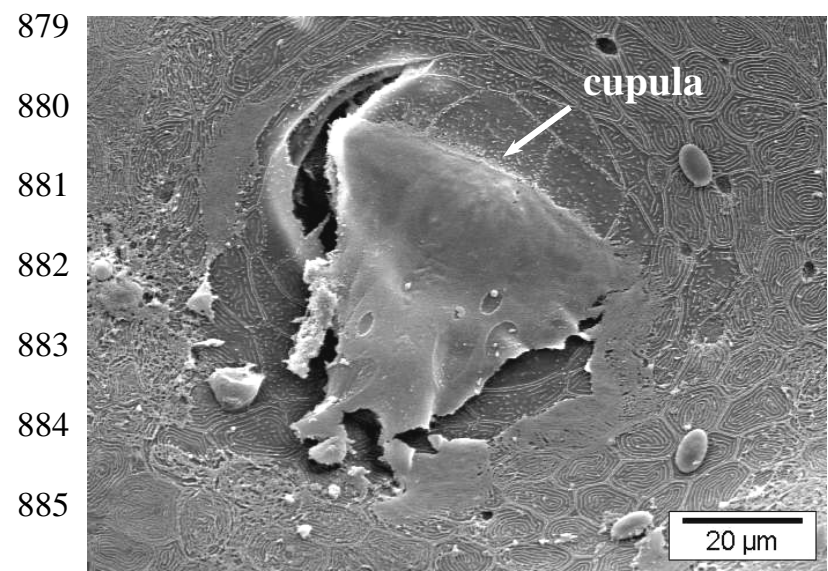

B

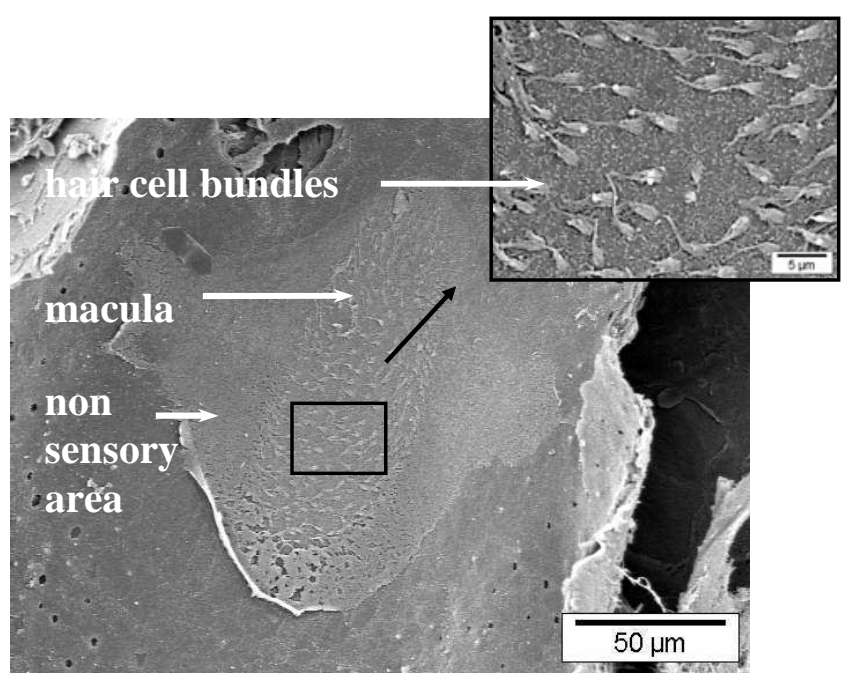

D

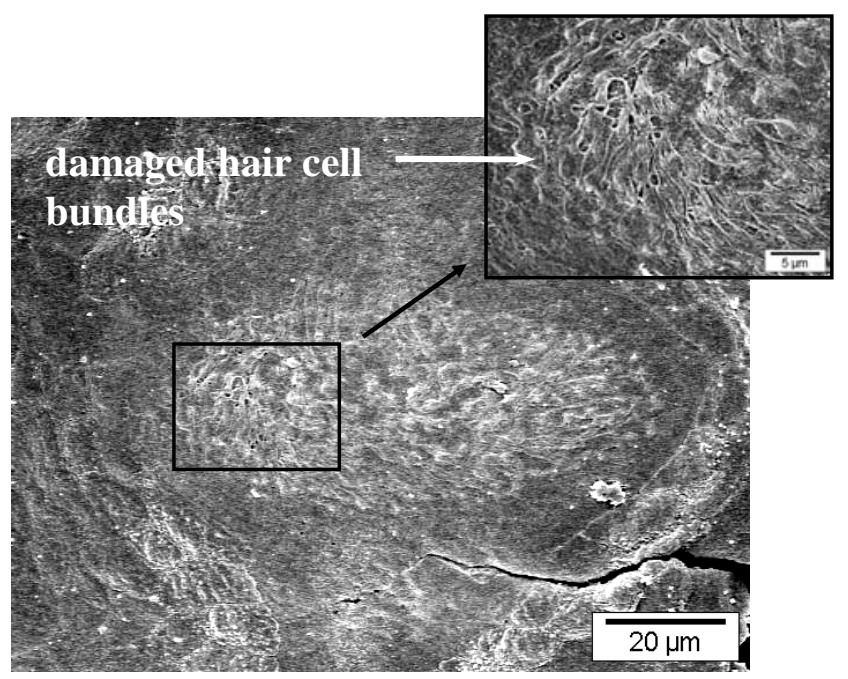

F

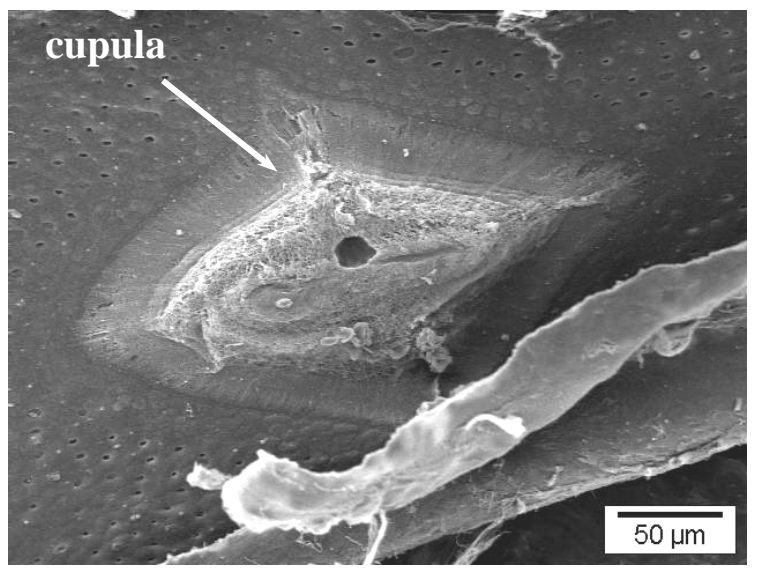




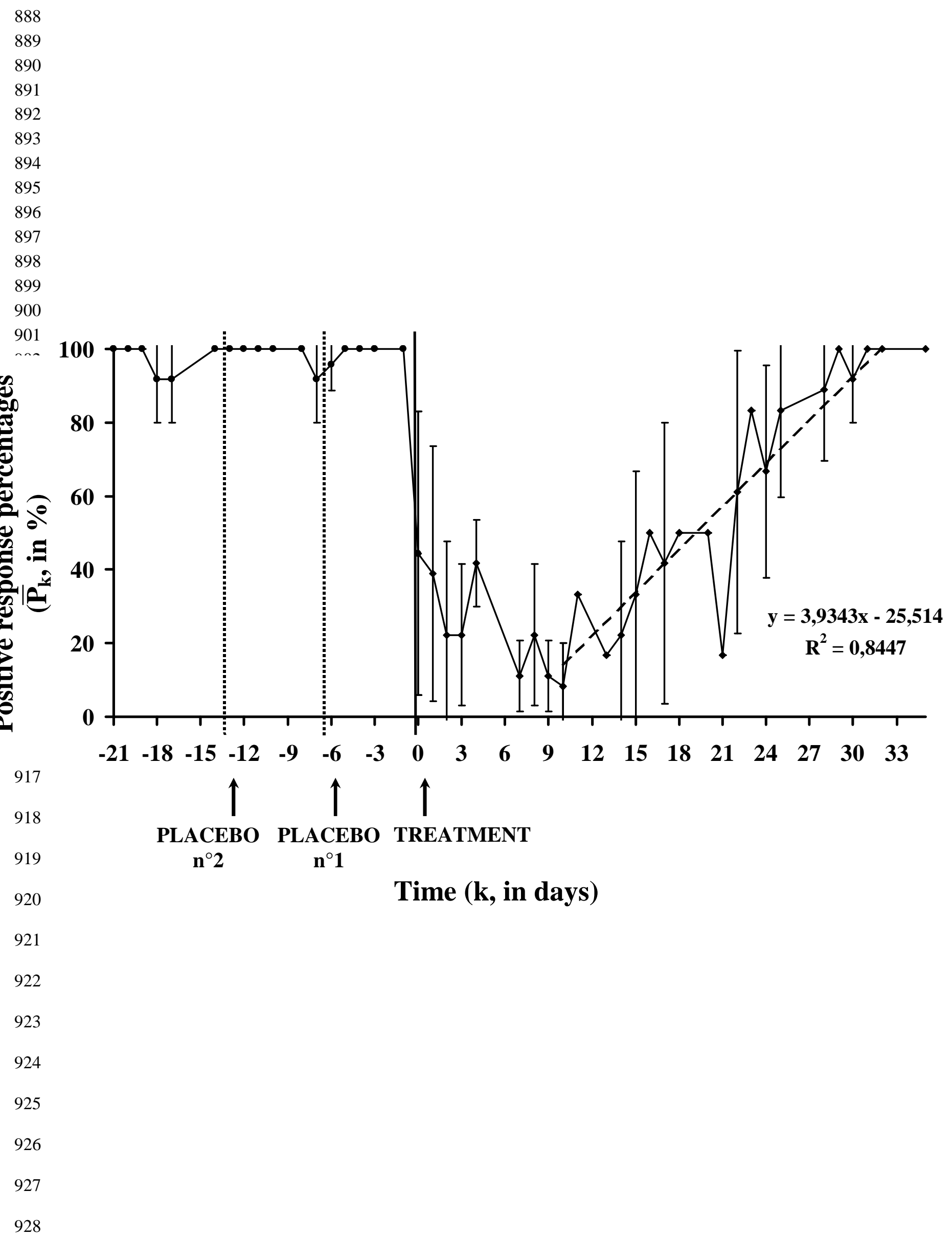


929 A

930

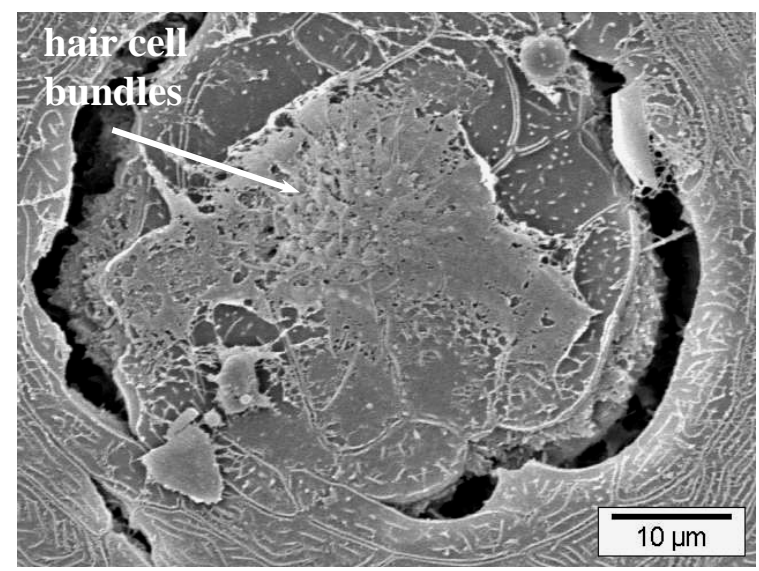

931

932

933

934

935

936

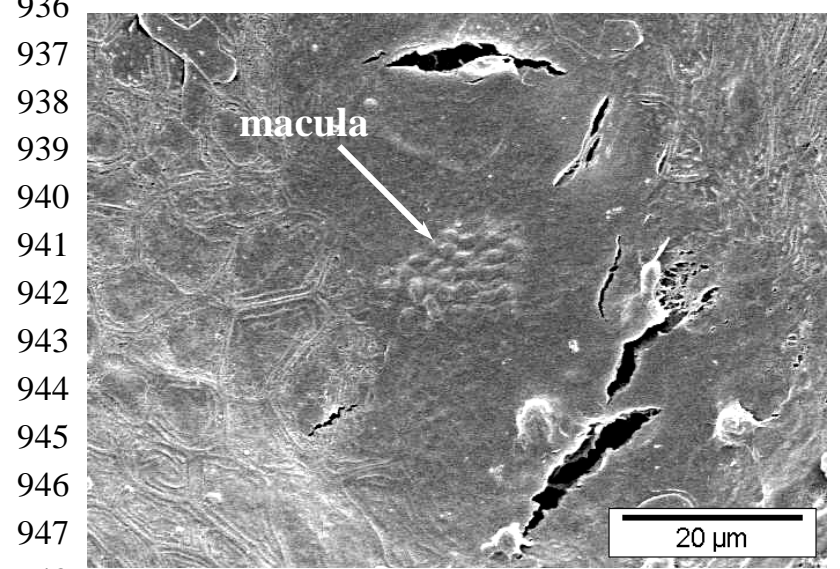

948

949

950

951

952

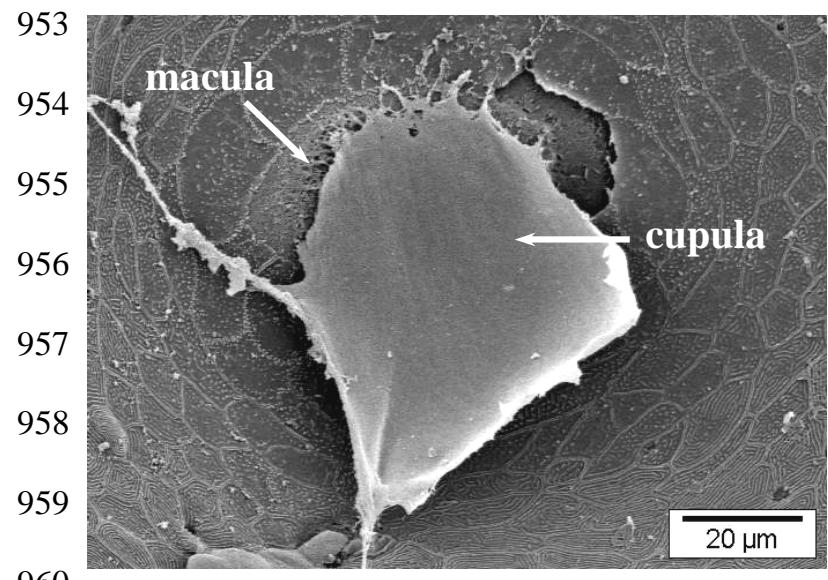

B

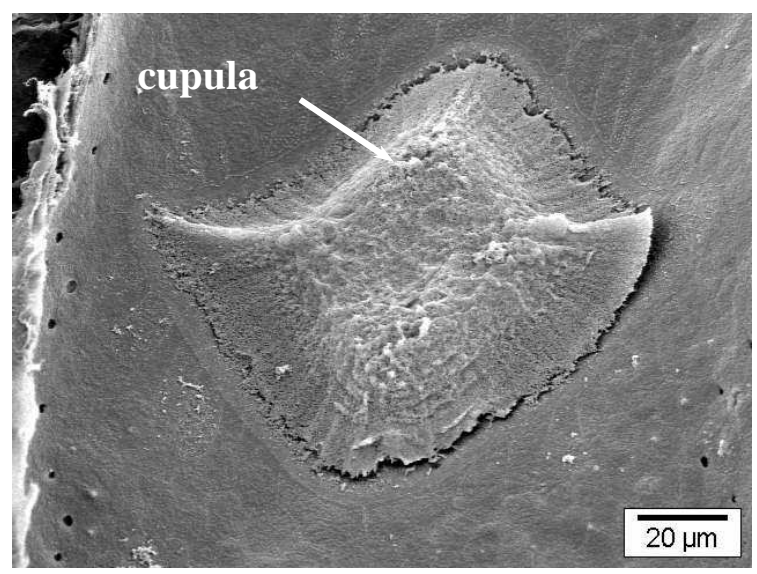

D

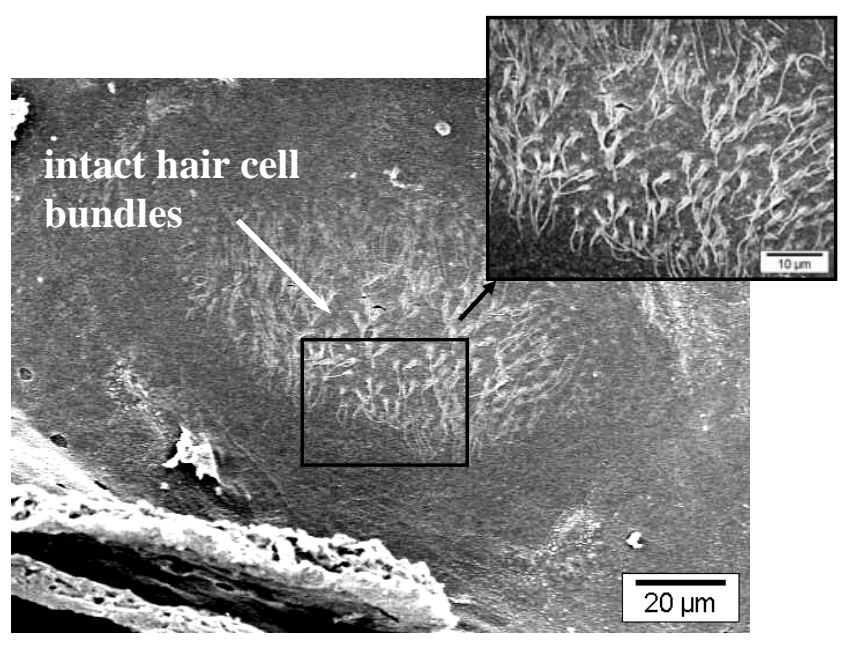

F

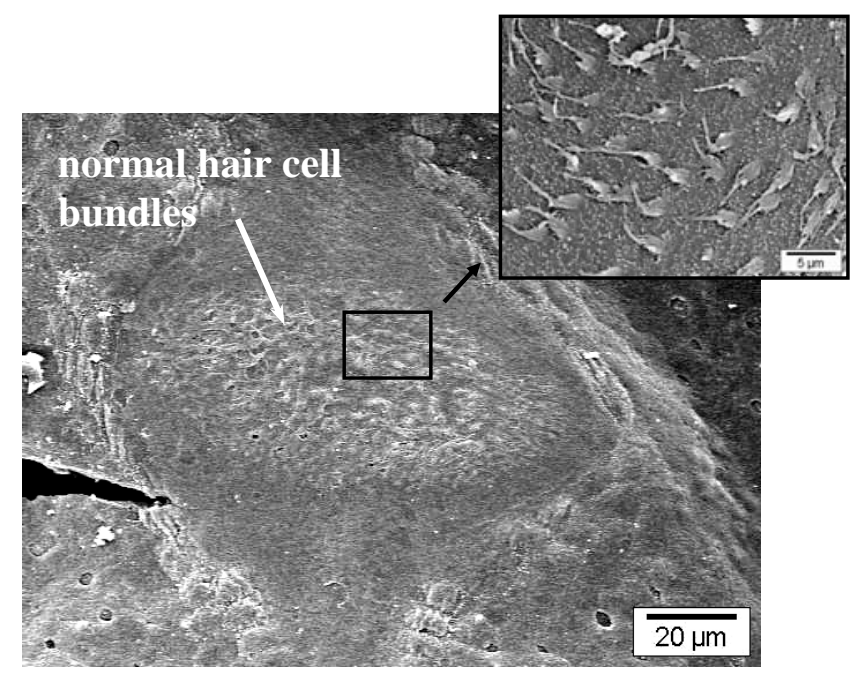




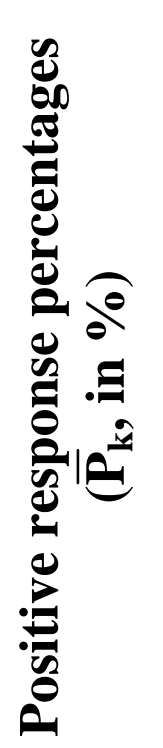

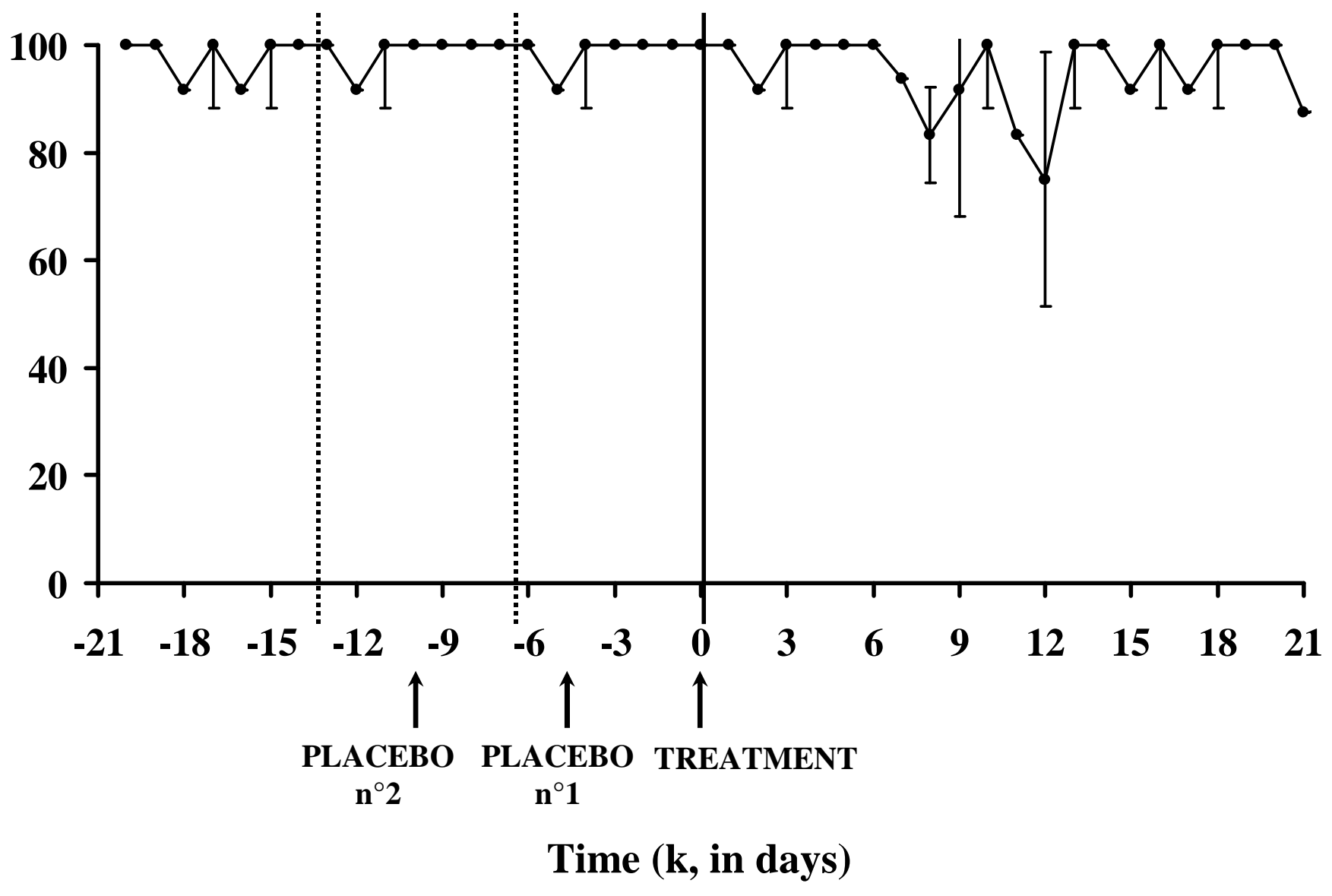




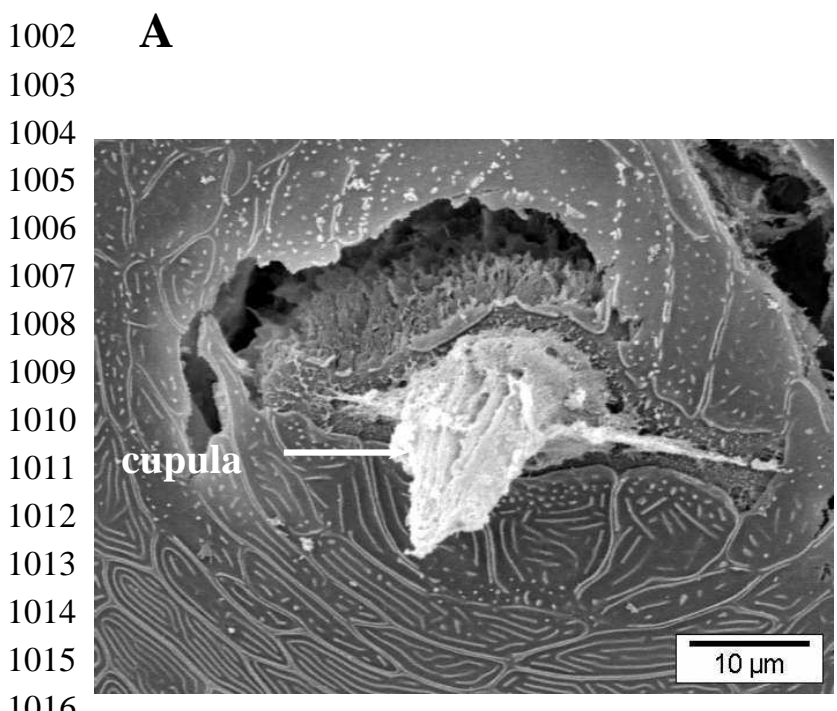

1017

1018 C

1019

1020

1021

1022

1023

1024

1025

1026

1027

1028

1029

1030

1031

1032

1033

1034

$1035 \mathrm{E}$

1036

1037

1038

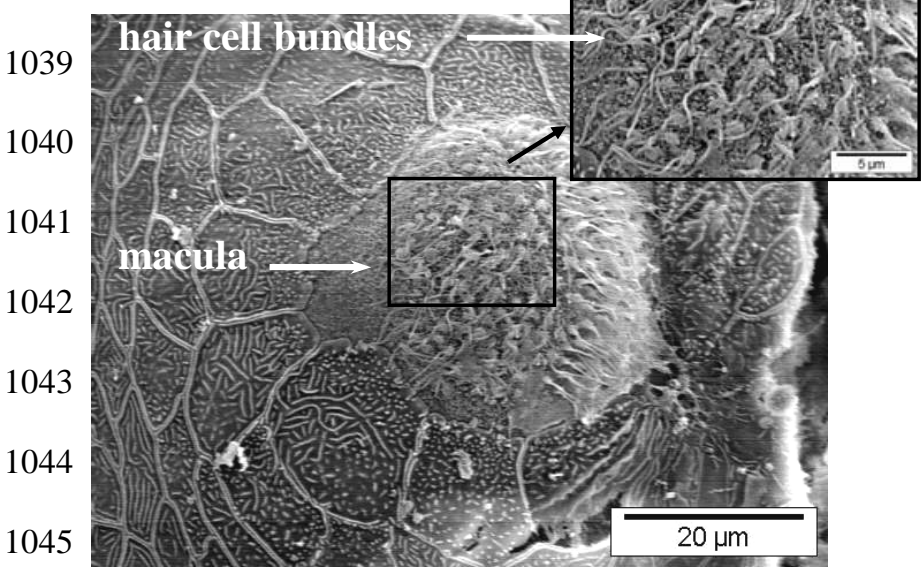

B

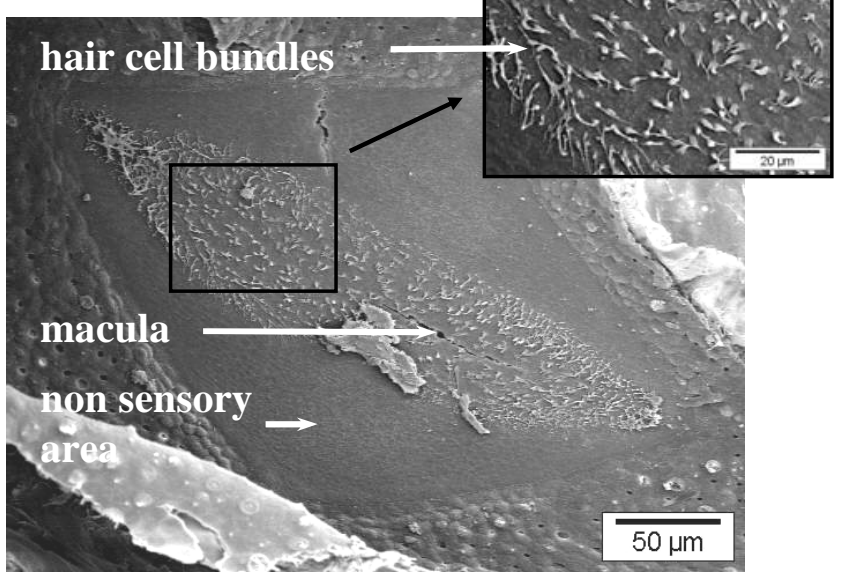

D

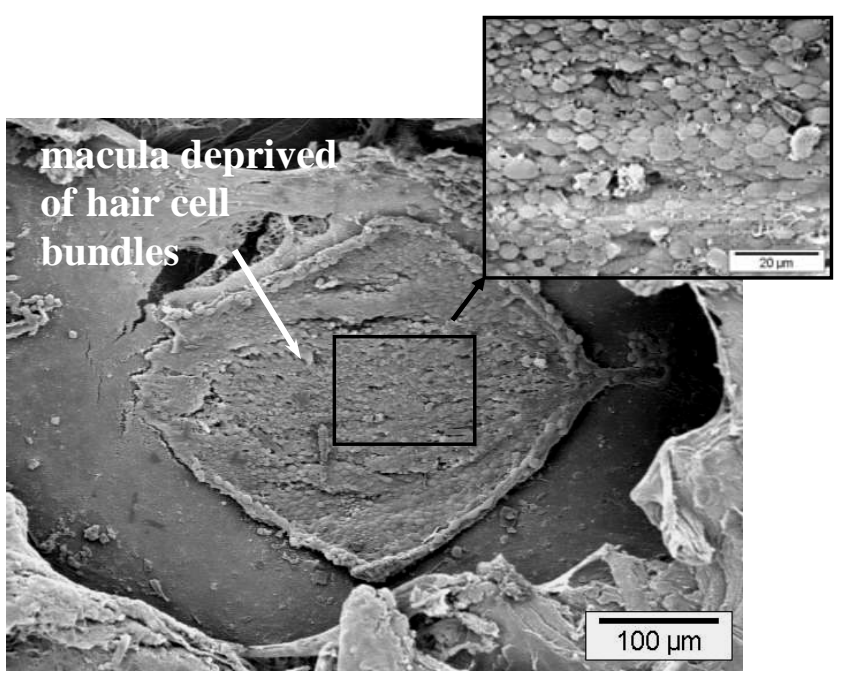

F

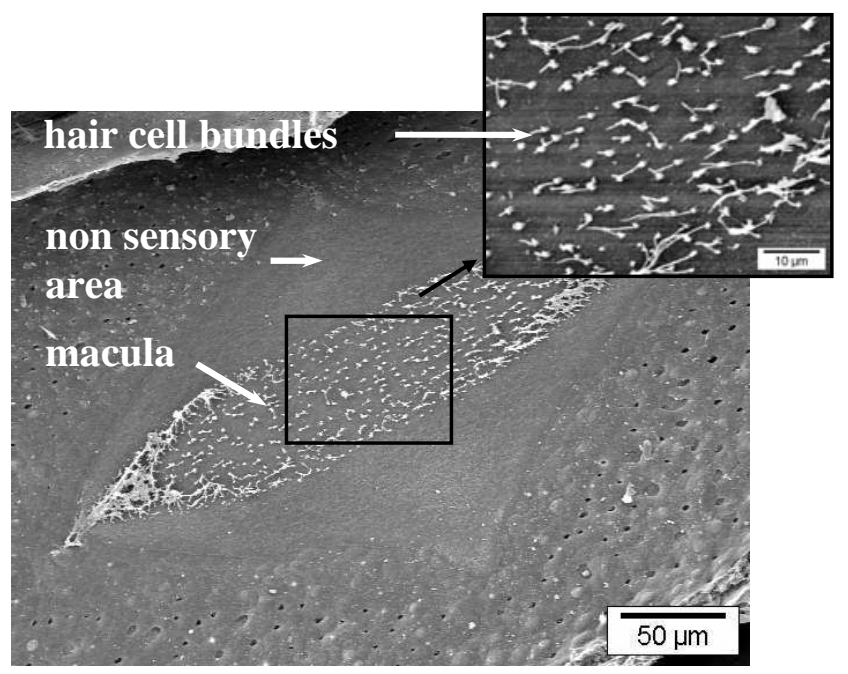


1047

1048

1049

1050

1051

1052

1053

1054

1055

1056

1057

1058

1059

बी

1076

1077

1078

1079

1080

1081

1082

1083

1084

1085

1086

1087

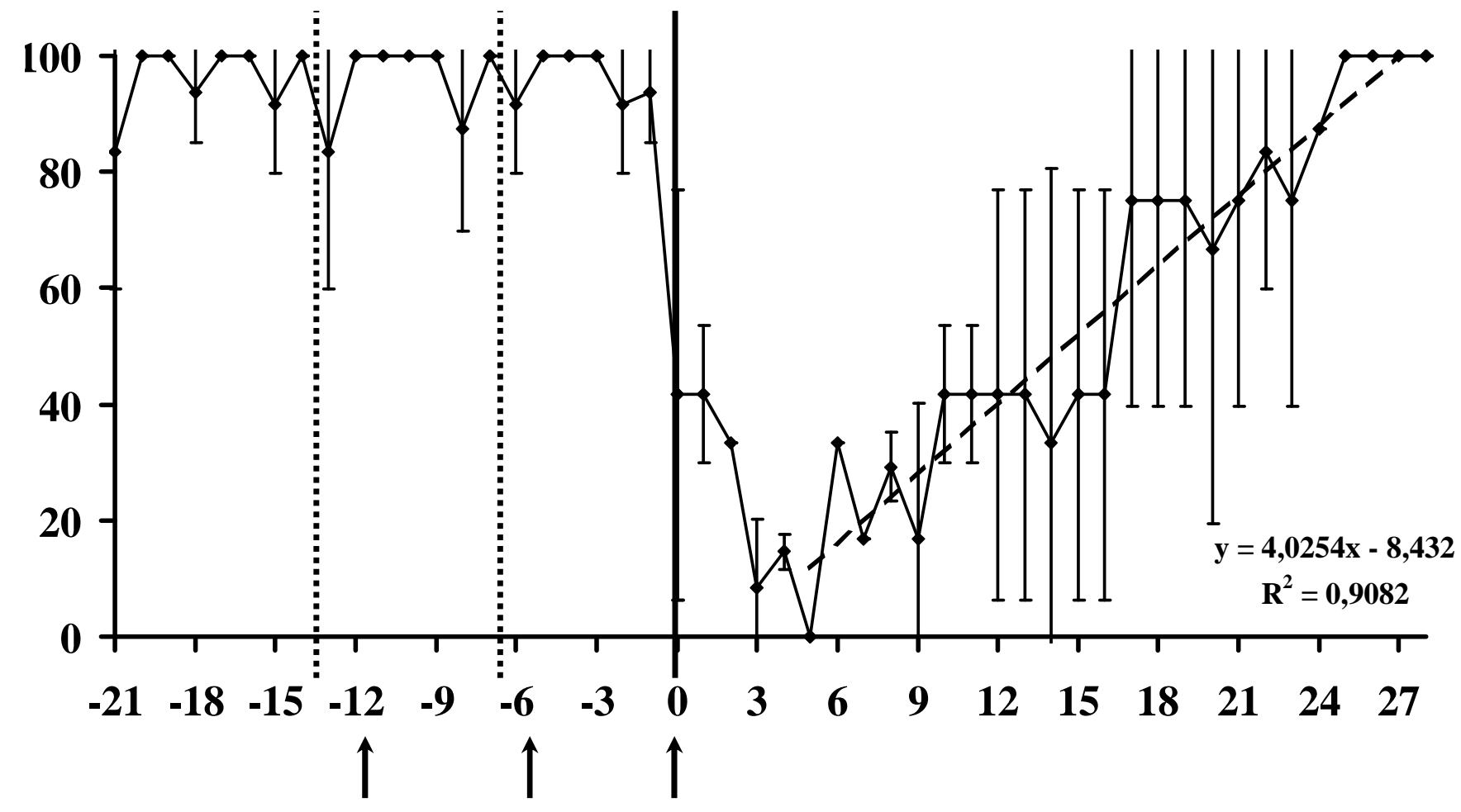

PLACEBO PLACEBO TREATMENT

$\mathrm{n}^{\circ} 2$

$\mathbf{n}^{\circ} 1$

Time (k, in days) 